\title{
Spatial analysis of the benefits and burdens of ecological focus areas for water-related ecosystem services vulnerable to climate change in Europe
}

\author{
J. Tzilivakis $^{1}$ (D) D. J. Warner ${ }^{1}$ • A. Green ${ }^{1}$ • K. A. Lewis ${ }^{1}$
}

Received: 9 January 2018 / Accepted: 20 March 2018 /Published online: 2 April 2018

(C) The Author(s) 2018

\begin{abstract}
There are many concerns regarding the effects of climate change including threats to ecosystem services. Rural land use can influence these services and there is scope for associated policies to steer decisions towards maximising benefits and minimising burdens. In Europe, for example, ecological focus areas (EFAs), introduced in the last reform of the Common Agricultural Policy, can have impacts on ecosystem services which vary with location, including potential trade-offs between benefits and burdens in some regions. This study combines the outputs from two continental-scale projects to provide a new perspective on the potential impact of EFAs for waterrelated ecosystem services under threat from climate change. An ecosystem service impact indicator framework was applied in conjunction with a climate change vulnerability assessment. This resulted in vulnerability and area weighted performance scores for dilution, filtration, water provision, and flood regulation services for 10 EFAs in 1256 regions. Best, average and worst case scenario maps were created that highlight the relative benefits and burdens of EFAs. Six EFAs have been identified which have not been activated in nine European Member States but which have potential to provide benefits. Eleven Member States have been identified which have regions where 3 EFAs should be avoided due to potential burdens. This analysis facilitates broad spatial targeting on a continental-scale of specific EFAs which may help maintain (and ideally increase) ecosystem service capacity and resilience in vulnerable regions.
\end{abstract}

Keywords Climate change $\cdot$ Ecological focus areas $\cdot$ Ecosystem services $\cdot$ Water

J. Tzilivakis

J.Tzilivakis@herts.ac.uk

1 Agriculture and Environment Research Unit (AERU), School of Life and Medical Sciences,

University of Hertfordshire, Hatfield AL10 9AB, UK 


\section{Introduction}

There are many concerns regarding the potential negative effects of climate change and amongst these are potential threats to ecosystem services such as increases in soil erosion and flooding, decreases in water provision and water quality and a reduction in pollination (Chang and Bonnette 2016; Dunford et al. 2015; Jentsch and Beierkuhnlein 2008; Maron et al. 2017; Lindner et al. 2010; Panagos et al. 2017; Runting et al. 2017; Vanbergen 2013; Wilby et al. 2010). Many of these services are influenced and impacted upon by agricultural land use practices. Consequently, policies that govern these, such as the Common Agricultural Policy (CAP) in Europe, can have benefits and burdens (positive and negative effects and impacts) on ecosystem services within a region, nation, across a whole continent such as Europe, and consequently globally. In the last reform of the CAP in 2013 (EC 2013a, b, c, d), a number of 'greening' measures were introduced, including a requirement for farms with more than 15 ha of arable land to dedicate at least $5 \%$ of their arable land to ecological focus areas (EFAs). As the name suggests, EFAs are land use and landscape features that potentially provide ecological benefits. Globally, this could include a broad range of land and features, but in the context of the European CAP it refers to a specific set of 19 land uses and features. The principal objective of these European EFAs is to contribute towards maintaining and enhancing biodiversity (EC 2013c), driven by the historic decline in farmland biodiversity (Chamberlain et al. 2000; Cresswell 2010; Donald et al. 2001; Goulson et al. 2008; Newton 2004; Temple and Terry 2007). However, EFAs may also have benefits for ecosystem services (Tzilivakis et al. 2015b) which have also been subject to declines in recent decades (Harrison et al. 2010; IPBES 2016; MEA 2005; SEP 2015).

The need to address historic and current issues has been at the core of many agrienvironmental policies and measures. However, there is an increasing need to also account for future threats (EEA 2009, 2011; SEP 2016). This includes near future issues, such as emerging pollutants (Brack et al. 2015) or medium- and long-term issues such as climate change. The latter of these is explored within this study, the objective of which was to combine the outputs from two continental-scale projects to provide a new perspective on the potential benefits and burdens of EFAs with respect to addressing climate change threats to waterrelated ecosystem services. An indicator framework to assess the ecosystem service impacts of EFAs (Tzilivakis et al. 2016) is applied in conjunction with an assessment of the vulnerability of ecosystem services to climate change (Tzilivakis et al. 2015a).

The indicator framework was developed to support a software tool, the EFA Calculator (AERU 2017), that aims to identify EFAs for a farm that offer the greatest potential benefits and least burdens. It takes into account numerous farm-specific geographical and management factors to derive performance scores for EFAs, thus steering farms towards selecting those with the highest performance score for their specific circumstances. The assessment of the vulnerability of ecosystem services to climate change was undertaken to support the development of the Optimal Strategies for Climate Change Action in Rural areas (OSCAR) software application (AERU 2013, 2014). OSCAR aims to assess the climate change mitigation and adaptation benefits and burdens of measures and operations available within the European Rural Development Programme (RDP). The adaptation assessment routines in OSCAR utilise the assessment of the vulnerability of ecosystem services to climate change to provide an assessment of the potential impact of RDP operations.

The overlap in these two projects, with respect to ecosystem services, provides scope to combine them and consequently provide new insights for future land use and management 
policy. In this study, the outputs of this combining process have been used to identify European regions where particular EFAs may be beneficial with respect to increasing ecosystem service capacity, and consequently increasing resilience and the ability to cope with climate change. This study has been applied in the context of the European continent, but the approaches utilised are sufficiently flexible to be applied to other countries and continents around the world. For example, the indicator framework could be tailored for other land uses and landscape features found outside of Europe and this could then be combined with climate change vulnerability assessments for non-European countries and continents. Additionally, many of the land use and landscape features examined (e.g. afforested areas, agroforestry, buffer strips, ditches, fallow land, ponds, etc.) are utilised elsewhere in the world, so understanding their benefits and burdens in a European context may be valuable when considering their potential impact elsewhere (especially when regional circumstances are similar).

\section{Methodology}

\subsection{Overview}

The EFA Calculator software (AERU 2017; Tzilivakis et al. 2015b) was used to assess the relative benefits and burdens for ecosystem services from different EFAs in each level 3 Nomenclature of Territorial Units for Statistics (NUTS3) region in the European Union (EU). These benefits/burdens were combined with the assessment of the vulnerability of ecosystem services to climate change identified in Tzilivakis et al. (2015a) to facilitate a spatial analysis. This analysis identifies regions where EFAs have the potential to increase the capacity of water-related ecosystem services, taking into account climate change vulnerabilities.

The approach can be broadly split into two steps:

1. Data generation: Creation of the NUTS3 farms (input data) and running this data through the EFA calculator to generate data on potential ecosystem service benefits and burdens for each farm for each EFA.

2. Data analysis: Processing data output from the EFA calculator to account for climate change vulnerabilities, including using geographical information systems (GIS) to visualise the results in a map format.

Tzilivakis et al. (2015a) assessed the vulnerability of regions to climate change in relation to nine ecosystem services. This study focuses on the four water-related services of dilution, filtration, flood regulation and water provision. These were selected for two reasons. Firstly, because the spatial attributes that influence the impact of EFAs on these services are likely to vary regionally. Secondly, the other services, such as soil erosion, migration and pollination, are influenced by more local circumstances (Morandin and Kremen 2013; Panagos et al. 2015; Shackelford et al. 2013; Wratten et al. 2012), the data for which are not available or suitable for this broad spatial analysis.

With respect to the EFAs, there are 19 that can be activated by Member States (MSs). Ten have been selected for inclusion in this study as they have the potential to affect the water-related ecosystem services selected. The EFAs are afforested areas, agroforestry, buffer strips, catch crops or green cover, ditches, fallow land, hedges or wooded strips, nitrogen fixing crops, ponds and short rotation coppice. The EFAs that have been excluded and their reasons for exclusion are: 
- Terraces: these only influence soil erosion in the indicator framework.

- Isolated trees, field margins, stone walls and strips along forest edges: these do not influence the water-related ecosystem services in the indicator framework. Field margins could have an impact on water-related services, but in that instance they would be considered buffer strips, and thus are included in this study under that EFA.

- Trees in line: the performance of this EFA in relation to water-related services is the same as hedgerows in the indicator framework, thus are included in this study under that EFA.

- Trees in groups and field copses: the performance of this EFA in relation to water-related services is the same as afforested areas in the indicator framework, thus are included in this study under that EFA.

\subsection{Data generation}

The EFA calculator (AERU 2017; Tzilivakis et al. 2015b) is a standalone Microsoft Windowsbased software application that was originally designed to assess individual farms. A user enters data about the farm and its features that can be declared as EFAs, with the latter referring to the parcels of land (e.g. fallow land, catch crops, etc.) and landscape features (e.g. hedgerows, ditches, woodland, ponds, etc.). Each EFA is described in the software using quantitative dimensions (area, width, height, etc.) and a number of qualitative parameters (with classes within those parameters, e.g. soil texture is a parameter, with classes of coarse, medium, medium fine, fine and very fine). The underlying indicator framework (Tzilivakis et al. 2016) utilises these dimensions and parameter classes to assess the relative performance of each EFA with respect to its potential benefits and burdens on ecosystem services. Parameters and parameter classes have different weights and scores, respectively, which vary based on the relative significance of those factors for each EFA for each ecosystem service. Thus when each EFA is defined using these parameters, a score is derived for each ecosystem service. The output is a relative performance index (not quantified impacts or absolute values) on a scale of -100 to +100 . Where data for some parameters are unknown, and thus unspecified, the software can calculate the worst, average and best case impacts for the feature, thus providing a potential range in impact.

Although the software is designed for use on individual farms, it has the potential to be used to support more strategic studies. For example, Angileri et al. (2017) used the tool to make an assessment of the potential impacts of EFA implementation at a regional level, by creating 121 hypothetical farms that were representative of a sample of NUTS3 regions across the EU (drawing upon data on the implementation of EFAs in those regions). A similar approach has been adopted in this study, except in this instance all NUTS3 regions have been assessed. However, running the EFA calculator software manually for all NUTS3 regions in the EU was not practical, therefore a bespoke batch processing routine was developed to automate the process. This included a parameterisation routine to automatically generate a farm for each region that has appropriate data for that region.

To create a farm for each NUTS3 region, the whole region was considered as a single farm. The size of the NUTS3 region and area of arable land in the region (sourced from EEA 2014) were used for the farm size and arable area respectively. Where the arable area for the region was zero, the region was excluded from the study. The data shown in Table 1 were used to derive region-specific parameter values for the farm. The EFA calculator software does account for more localised and/or management parameters, but these cannot 
Table 1 Spatial data used to define regional parameters

\begin{tabular}{|c|c|c|}
\hline Data & Description & Reference \\
\hline NUTS3 and arable areas & $\begin{array}{c}\text { The area in hectares (ha) of the NUTS } 3 \text { region } \\
\text { and the area of arable land in that region }\end{array}$ & EEA (2014) \\
\hline Annual precipitation & $\begin{array}{l}\text { The mean annual precipitation in millimetres } \\
(\mathrm{mm}) \text { for the NUTS3 region }\end{array}$ & JRC (2012a) \\
\hline Soil texture & $\begin{array}{l}\text { Dominant surface textural class of the soil. } \\
\text { Class used is the majority value in the } \\
\text { NUTS3 region }\end{array}$ & JRC (2012b) \\
\hline Water stress & $\begin{array}{l}\text { The water stress in the region. The mean value } \\
\text { is used for the NUTS3 region }\end{array}$ & Vörösmarty et al. (2010) \\
\hline Annual temperature & $\begin{array}{l}\text { The mean annual temperature value for the } \\
\text { NUTS } 3 \text { region }\end{array}$ & Climate Research Unit (2017) \\
\hline Ecological zone & $\begin{array}{l}\text { The IPCC Ecological Zone. Class used is the } \\
\text { majority value in the NUTS3 region }\end{array}$ & $\operatorname{ESDAC}(2017 a)$ \\
\hline Soil hydraulic conductivity & $\begin{array}{l}\text { The soil hydraulic conductivity. The mean } \\
\text { value is used for the NUTS3 region }\end{array}$ & ESDAC (2017b) \\
\hline Gradient & $\begin{array}{l}\text { The typical gradient in the region. Majority } \\
\text { value for the NUTS } 3 \text { region is used based } \\
\text { on SLOPEM value from dataset }\end{array}$ & ESDAC (2017c) \\
\hline Average field size & $\begin{array}{l}\text { The average field size. The mean value is used } \\
\text { for the NUTS } 3 \text { region (Note: field sizes are } \\
\text { likely to be highly variable within a region. } \\
\text { It should be acknowledged that the average } \\
\text { could be skewed and that this is a crude } \\
\text { regional value) }\end{array}$ & ESDAC (2017d) \\
\hline $\begin{array}{l}\text { Buffering capacity of } \\
\text { soils and rocks }\end{array}$ & $\begin{array}{l}\text { The anion filtering capacity of soils used as the } \\
\text { basis for determining a class for the NUTS3 } \\
\text { region from very low to very high }\end{array}$ & ESDAC (2017c) \\
\hline Acid deposition & $\begin{array}{l}\text { Estimated acid deposition. The mean value is } \\
\text { used for the NUTS3 region }\end{array}$ & EEA (2017) \\
\hline Nutrient deposition & $\begin{array}{l}\text { Estimated nutrient deposition. The mean value } \\
\text { is used for the NUTS3 region }\end{array}$ & EEA (2017) \\
\hline
\end{tabular}

be defined at a regional scale. The data for these parameters for each EFA were not set, i.e. were unspecified. Consequently, as described above, the known parameter values for each region in combination with the best and worst unspecified parameters were used to calculate worst, average and best case scenario values. Finally, to facilitate an individual analysis of each of the ten EFAs, a version of the farm was created to assess each EFA, with the area being set to $5 \%$ of the arable area. An example farm for Mittelburgenland in Austria (AT111) is shown in Table 2.

The process above resulted in 1256 NUTS3 farms, which were duplicated for each of the 10 EFAs, resulting in 12,560 files. These were then run through the EFA calculator twice, to generate a worst case and best case value for each impact, with the average case value calculated from these two values. Thus there were 37,680 sets of impact performance values output from the EFA calculator.

\subsection{Data analysis}

The data generated from the approach described in Section 2.2 needed to be combined with water-related ecosystem service vulnerability outputs from Tzilivakis et al. (2015a). In summary, these were: 
Table 2 Example farm data

\begin{tabular}{ll}
\hline Item & Value \\
\hline Farm area (ha) & 70,457 \\
Arable area (ha) & $27,837.5$ \\
Feature area (square metres $\left.\left(\mathrm{m}^{2}\right)\right)$ & $13,918,250$ \\
Buffering capacity of soils and rocks & High $(\mathrm{e} . \mathrm{g}$. containing considerable calcium carbonate) \\
Ecological zone & Temperate continental forest \\
Feature & Woodland \\
Average field size & $\geq 10$ ha \\
Gradient (band) & 10 to $20 \%$ \\
Hydraulic conductivity of the soil & Moderate \\
Mean annual precipitation & $<1000 \mathrm{~mm}$ high $(647-765 \mathrm{~mm})$ \\
Mean annual temperature & 6 to $10{ }^{\circ} \mathrm{C}$ \\
Regional water stress & High \\
Risk of acid deposition & Very low \\
Risk of nutrient deposition & Moderate \\
Soil texture & Medium \\
\hline
\end{tabular}

${ }^{a}$ Two bands are derived for mean annual precipitation as these parameter classes are required to assess the impact of different ecosystem services

- Dilution: regions where there are water quality issues and where climate change projections predict a decrease in summer and winter rainfall, thus reducing the capacity for dilution and increasing the concentration of pollutants.

- Filtration: regions where there are water quality issues and where climate change projections predict an increase in run-off within the region, thus requiring an increase in the filtration capacity in the region.

- Flood regulation: regions where damage from flooding is projected to increase as a consequence of climate change, based on the results of the PESETA (Projection of Economic impacts of climate change in Sectors of the European Union based on bottom-up Analysis) project (Ciscar et al. 2009).

- Water provision: regions which already suffer from water stress and where climate change projections predict a decrease in summer and winter rainfall, thus reducing the supply of water in the region.

The ecosystem service classification used by Tzilivakis et al. (2015a) is different to that used in the EFA calculator and indicator framework (Tzilivakis et al. 2016). The latter uses Version 4 of the Common International Classification of Ecosystem Services (CICES) system (Haines-Young and Potschin 2013), whereas the former uses a bespoke system. Therefore the classification of Tzilivakis et al. (2015a) was 'mapped' to the CICES classification in order to harmonise the two approaches and facilitate analysis as shown in Table 3 (Notes: (i) CICES uses a hierarchical classification, which is shown in Table 3; (ii) the latest version of CICES (Version 5.1) was not available at the time the study was undertaken. However, the extensions and revisions in the latest version do not impact upon the results presented in this study).

Deriving an assessment of the potential performance of EFAs in relation to the climate change vulnerabilities (Tzilivakis et al. 2015a) was undertaken in two stages. Firstly, the outputs from the EFA calculator were adapted using a weighting factor to generate a vulnerability weighted performance score for each EFA, for each ecosystem 
Table 3 Mapping of ecosystem service classifications

\begin{tabular}{|c|c|c|c|c|}
\hline \multirow{2}{*}{$\begin{array}{l}\text { Classification } \\
\text { (Tzilivakis et al. } \\
\text { 2015a) }\end{array}$} & \multicolumn{4}{|c|}{$\begin{array}{l}\text { Common International Classification of Ecosystem Services (CICES) (Haines-Young and } \\
\text { Potschin 2013) }\end{array}$} \\
\hline & Section & Division & Group & Class \\
\hline Dilution & $\begin{array}{r}\text { Regulation and } \\
\text { maintenance }\end{array}$ & $\begin{array}{l}\text { Maintenance of physical, } \\
\text { chemical, biological } \\
\text { conditions }\end{array}$ & Water conditions & $\begin{array}{l}\text { Chemical condition } \\
\text { of freshwaters }\end{array}$ \\
\hline Filtration $^{\mathrm{a}}$ & $\begin{array}{r}\text { Regulation and } \\
\text { maintenance }\end{array}$ & $\begin{array}{l}\text { Maintenance of physical, } \\
\text { chemical, biological } \\
\text { conditions }\end{array}$ & Water conditions & $\begin{array}{l}\text { Chemical condition } \\
\text { of freshwaters }\end{array}$ \\
\hline Flood regulation & $\begin{array}{l}\text { Regulation and } \\
\text { maintenance }\end{array}$ & Mediation of flows & Liquid flows & Flood protection \\
\hline \multirow[t]{2}{*}{ Water provision } & Provisioning & Nutrition & Water & - \\
\hline & Provisioning & Materials & Water & - \\
\hline
\end{tabular}

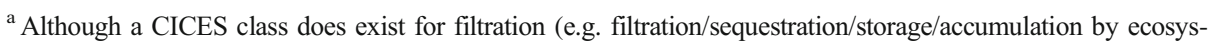
tems), the assessment of the performance of EFAs in the indicator framework (Tzilivakis et al. 2016) is more focused on the outcome, i.e. water quality in this instance. Hence filtration has been associated with the CICES chemical condition of freshwaters class

service, in each region. Equation 1 shows the main equation to derive this weighted score.

$$
\text { Score }_{\mathrm{VW}}=\text { Score } \times \frac{\mathrm{VC}_{\mathrm{W}}}{100}
$$

Where:

Score $_{\mathrm{VW}} \quad$ Vulnerability weighted performance score

Score Unweighted performance score for an EFA for an ecosystem service

$\mathrm{VC}_{\mathrm{W}} \quad$ Normalised vulnerability class weighting factor (see Eq. 2)

The vulnerability classes were normalised on to a 0 to 100 scale using Eq. 2. The vulnerability classes needed a simple normalisation factor to convert them to a 0 to 100 scale.

$$
V C_{W}=\frac{V C \times N f}{100}
$$

Where:

$\mathrm{VC}_{\mathrm{W}} \quad$ Normalised vulnerability class weighting factor

VC Vulnerability class

Nf Normalisation factor: the vulnerability classes derived by Tzilivakis et al. (2015a)

have variable scales, e.g. $1-10$ or 1 to 70 , so required converting to a scale of 1 to 100 by applying a normalisation factor, e.g. flood regulation is 0 to 10 , so a normalisation factor of 10 is applied to convert the class

Those EFAs that have a high vulnerability weighted performance score are likely to be the most beneficial with respect to enhancing those ecosystem services in regions where they are most vulnerable to climate change. 
The second stage accounts for the potential extent an EFA could be implemented within a region. This was done by using the percent arable area in a region to provide an area and vulnerability weighted performance score (Score ${ }_{\mathrm{VAW}}$ ) using Eq. 3.

$$
\text { Score }_{\mathrm{VAW}}=\text { Score }_{\mathrm{VW}} \times A A
$$

Where:

Score $_{\text {VAW }}$ Vulnerability and area weighted performance score

Score $_{\mathrm{VW}} \quad$ Vulnerability weighted performance score

AA Percentage of arable area of the region (expressed as a fraction between 0 and 1)

The above process resulted in 105,504 items of data (1256 NUTS3 regions $\times 2$ impact values [positive and negative] $\times 3$ scenarios [worst, average and best] $\times 14 \mathrm{EFA}$ - ecosystem service combinations). It is not feasible, or particularly useful, to present this raw data in its entirety herein. Therefore to aid interpretation, the weighted performance scores were imported into a GIS compatible database and maps of NUTS3 regions were created using version 2.18 of QGIS (QGIS Development Team 2017). The coordinate reference system (CRS) used for the maps is ETRS89-LAEA Europe, also known in the EPSG Geodetic Parameter Dataset under the identifier: EPSG:3035. A worst, average and best case map has been created for each EFA - ecosystem service combination using the vulnerability and area weighted performance score $\left(\right.$ Score $\left._{\mathrm{VAW}}\right)$. The shading on the maps is red for burdens and green for benefits, with

Table 4 Potential benefits and burdens of EFAs on vulnerable ecosystem services

\begin{tabular}{|c|c|c|c|c|c|c|}
\hline \multirow[t]{2}{*}{ Ecosystem service and EFA } & \multicolumn{2}{|l|}{ Score } & \multicolumn{2}{|c|}{ Score $_{\mathrm{VW}}$} & \multicolumn{2}{|c|}{ Score $_{\text {VAW }}$} \\
\hline & Worst & Best & Worst & Best & Worst & Best \\
\hline \multicolumn{7}{|l|}{ Dilution } \\
\hline Afforested areas & -100 & -4 & -29 & 0 & -8 & 0 \\
\hline Agroforestry & -3 & 0 & -1 & 0 & -1 & 0 \\
\hline Buffer strips & -15 & 78 & -2 & 41 & -1 & 16 \\
\hline Catch crops or green cover & -6 & 36 & -1 & 17 & -1 & 7 \\
\hline Ditches & -20 & 75 & -11 & 41 & -4 & 16 \\
\hline Fallow land & -36 & 2 & -14 & 0 & -4 & 0 \\
\hline Hedges or wooded strips & 0 & 100 & 0 & 54 & 0 & 21 \\
\hline Nitrogen fixing crops & -41 & 0 & -16 & 0 & -5 & 0 \\
\hline Ponds & 6 & 97 & 0 & 51 & 0 & 20 \\
\hline Short rotation coppice & -2 & 0 & -1 & 0 & -1 & 0 \\
\hline \multicolumn{7}{|l|}{ Filtration } \\
\hline Buffer strips & -15 & 78 & -2 & 51 & -1 & 25 \\
\hline \multicolumn{7}{|l|}{ Flood regulation } \\
\hline Afforested areas & 28 & 100 & 0 & 81 & 0 & 48 \\
\hline Ditches & 0 & 100 & 0 & 100 & 0 & 59 \\
\hline \multicolumn{7}{|l|}{ Water provision } \\
\hline Afforested areas & -94 & -7 & -94 & 0 & -72 & 0 \\
\hline
\end{tabular}

It is important to note that the numbers shown in Table 4 are the relative performance for the specific EFA only (i.e. not absolute values for the ecosystem services) and thus should not be used to compare one EFA to another. For example, a best case score of 16 for dilution for buffer strips is not equivalent to the score of 16 for dilution for ditches. It simply means they both have a moderate potential to contribute to dilution in their own specific way in regions where they achieve this score 
darker shades representing greater burdens or benefits. The gradient of the shading is based on the worst and best case values for each EFA for each ecosystem service (as shown in Table 4).

\section{Results}

\subsection{Introduction and overview}

Table 4 provides an overview of the worst and best unweighted and weighted performance scores for each EFA. The regional variability in the performance of the different EFAs for each ecosystem service is illustrated in the maps shown in Figs. 1, 2, 3, 4, 5, 6, 7, 8, 9, 10, 11, 12, 13 and 14 (worst, average and best case scenarios from left to right) and main observations for each EFA have been drawn out in the discussion.

\section{Discussion}

\subsection{Interpretation and implications for EFA activation and implementation}

This section explores the results of the spatial analysis with respect to countries and regions across Europe that have or have not activated each EFA. Table 5 provides an overview of which EFAs each MS has activated (note there are 32 as the UK and Belgium are split into 4 and 2 regions respectively) and Table 6 provides some example results for individual NUTS3 regions that are mentioned below.

Afforested areas The unweighted scores for afforested areas (Table 4) indicate that there are regions where the combination of attributes means that potential benefits and burdens are maximised (as indicated by the -100 and +100 scores). For dilution, the vulnerability (Score ${ }_{\mathrm{Vw}}$ ) and area and vulnerability (Score ${ }_{\mathrm{vAW}}$ ) weighted scores are significantly lower, indicating that high vulnerability is not coinciding with the attributes for maximum impact and/or a high proportion of arable land in the region. This lack of coincidence is less so for flood regulation and water provision which have higher Score $_{\text {Vw }}$ and Score $_{\text {VAw }}$ values. Thus it can be concluded that the implementation (or avoidance) of afforested areas has the greatest potential benefits with respect to flood regulation and burdens with respect to water provision, and lesser potential burdens with respect to dilution.
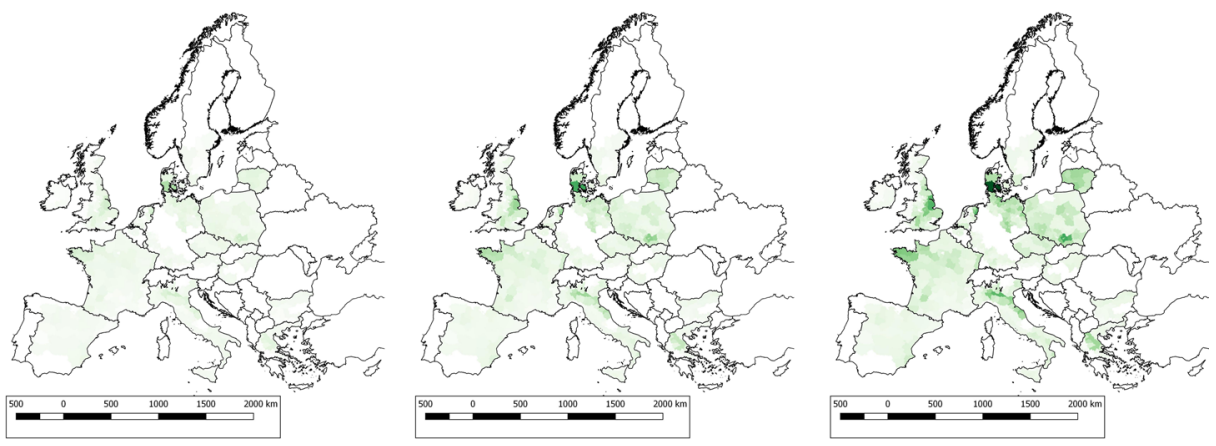

Fig. 1 Afforested areas: flood regulation 

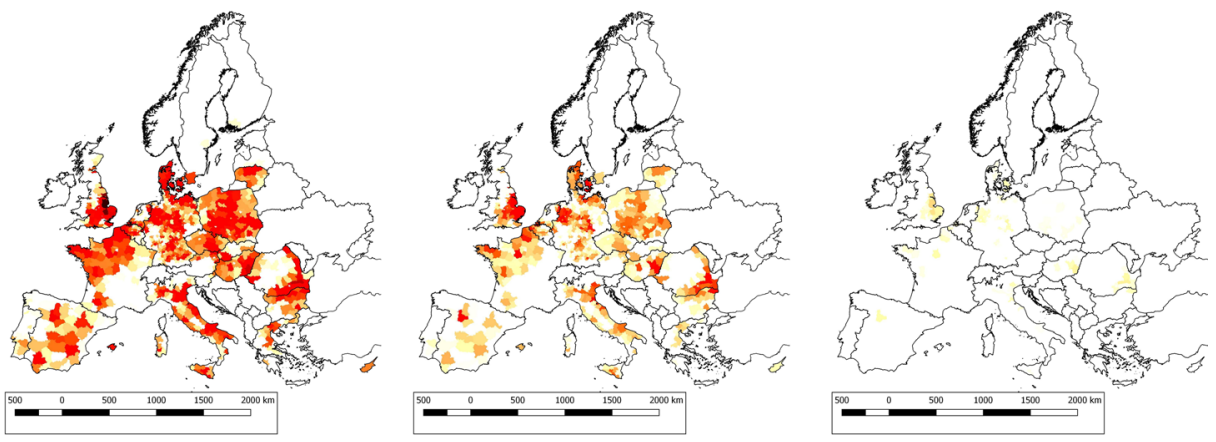

Fig. 2 Afforested areas: water provision

The areas with the greatest potential benefits for flood regulation are those where the vulnerability to flooding is high, annual rainfall is high and there is a high proportion of arable land (thus high potential to implement this land use as an EFA). This includes central Denmark, eastern England, northwest France, central-northern Italy, central Greece, north-east Germany, southern Poland and Lithuania (see Fig. 1). There are some minor differences between the worst to best case scenarios. The areas with the greatest potential burdens for water provision are those where the region is vulnerable (i.e. currently water stressed and predicted to become warmer and drier) and paradoxically where rainfall is high (as there is greater scope for a reduction in water provision). This includes eastern-England, Denmark, northern France, central Spain, central Germany, Poland, eastern Italy, Hungary and southeast Romania (see Fig. 2). There are some major differences between the worst and best case scenarios, with the best case scenario eliminating any significant burdens, whilst the worst case scenario significantly extends the number of regions where burdens could occur. There are other more localised and management factors, which have not been specified in this spatial analysis, which affect the benefits and burdens (these unspecified factors contribute the difference between the worst and best case scenarios). These are that older woodlands (20+ years) tend to have a greater effect on flood regulation and water provision (Farley et al. 2005), with coniferous woodland having a slightly greater effect than broadleaved woodland (Sahin and Hall 1996).

The areas with the greatest potential burdens for dilution are those where vulnerability to dilution is high (i.e. where the current chemical condition of water is low, and the region is predicted to become drier resulting in less volume of water) and where the risk of acid and nutrient deposition is high and the buffering capacity of the soil is low. This includes include
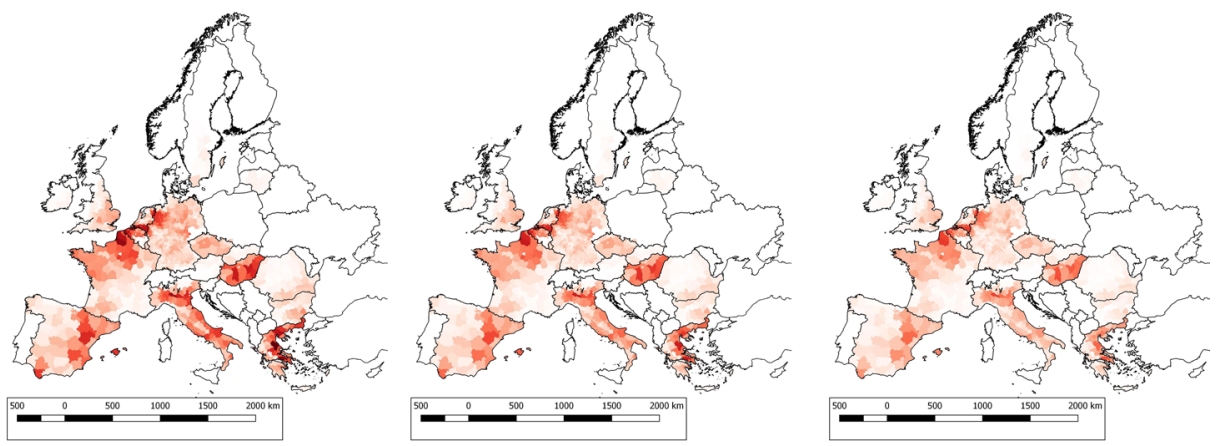

Fig. 3 Afforested areas: dilution 

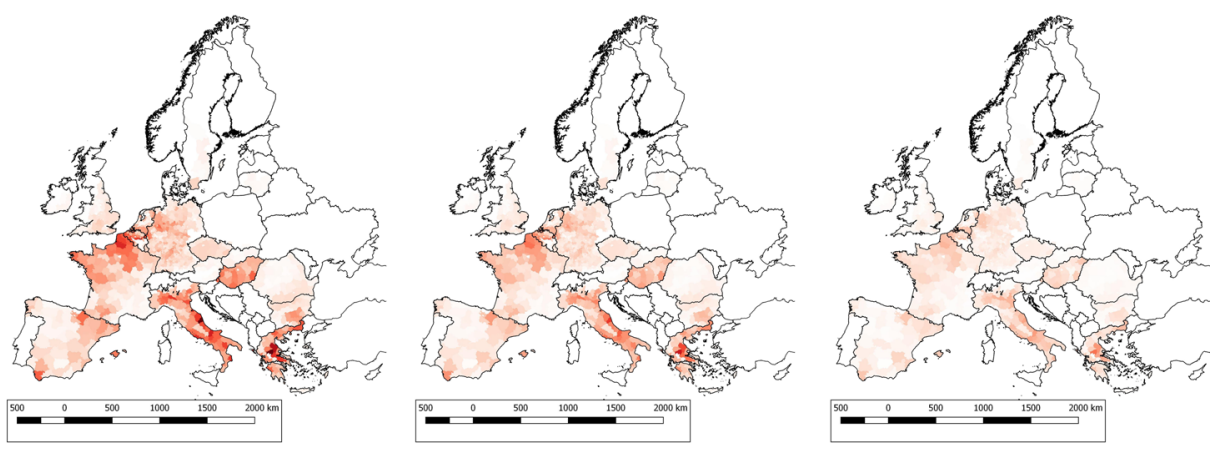

Fig. 4 Agroforestry: dilution

northern France and Belgium, eastern Spain, south and eastern Netherlands, western Germany, north and eastern Italy, Hungary and eastern Greece (see Fig. 3). There are some minor differences between the worst to best case scenarios. Other more geographically localised and/ or management factors that influence the burdens and were unspecified are woodland type (with coniferous and eucalypts having a greater burden than broadleaved woodland), and whether the woodland is commercially harvested or not, with commercially harvested woodlands having a slightly lower burden (Allen and Chapman 2001; Bastrup-Birk and Gundersen 2004).

There are eight MSs that have not activated the 'afforested areas' or the 'trees in groups and field copses' EFAs. Two of these have been identified as having significant potential for benefits for flood regulation (based on the combination of the performance of the EFA, the vulnerability and the area of arable land). These are (with example regions) Denmark (e.g. Sydjylland-DK032) and UK-England (e.g. Lincolnshire-UKF30). A further nine MSs have activated 'trees in groups and field copses' only, and two of these have been identified as having significant potential for benefits for flood regulation should there be more uptake of afforested areas. These are Greece (e.g. Larisa_EL612) and Lithuania (e.g. Siauliu apskritisLT006).

It could be argued that these MSs should consider activating the 'afforested areas' EFA. However, there are also burdens from afforested areas on water provision and dilution. In many respects, this is a trade-off as the consequence of forests retaining water (to minimise flooding) is that this can reduce water provision and dilution downstream in the catchment. However, this trade-off depends on the circumstances of each region. With regard to water
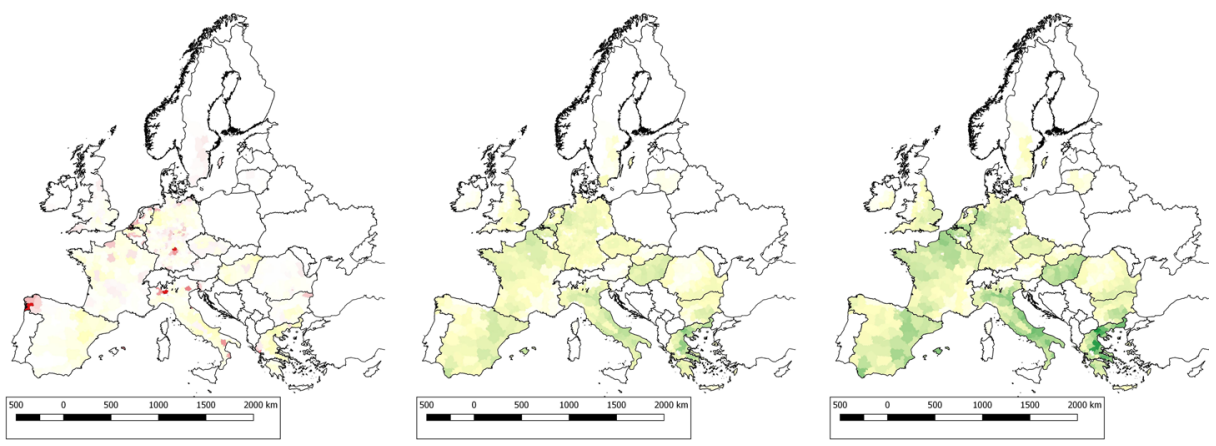

Fig. 5 Buffer strips: dilution 

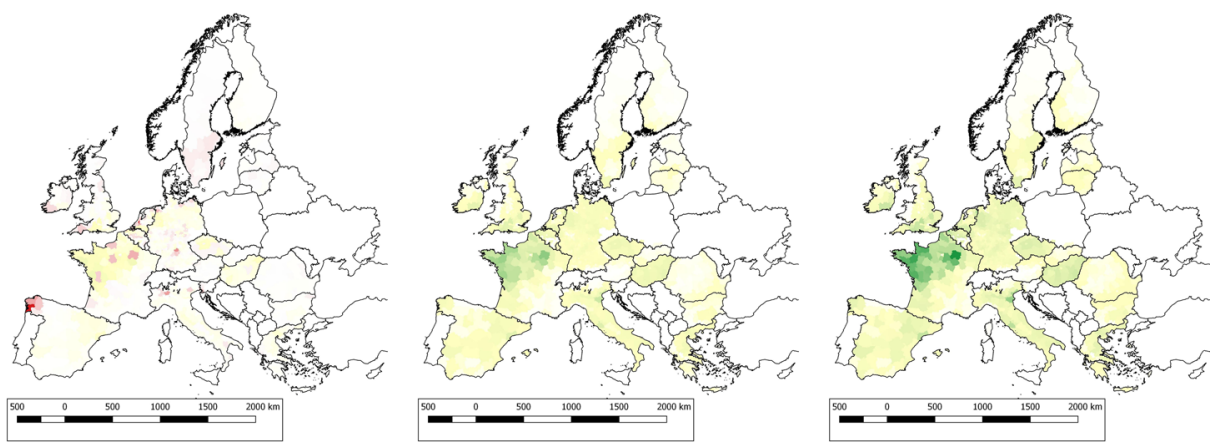

Fig. 6 Buffer strips: filtration

provision, France, Germany, Hungary, Italy, Poland, Romania and Spain have all activated 'afforested areas' and have areas where there could be significant burdens on water provision (e.g. Eure-et-Loir-FR242, Salzland-DEE0C, Bekes-HU332, Treviso-ITD34, Lubelski-PL314, Ialomita_-RO315 and Valladolid-ES418). Denmark and England, which could gain benefits for flood regulation by activating this EFA, also have areas that would experience significant burdens on water provision. Thus if activated, the potential trade-offs would need to be considered on a region by region basis. Potential dilution issues have been identified for Belgium, France, Germany, Italy, Spain which have activated 'afforested areas' and Greece and the Netherlands which have activated 'trees in groups and field copses' (e.g. Arr. Ieper-BE253, Somme-FR223, Emsland-DE949, Cremona-ITC4A, TeruelES242, Larisa-EL612 and Oost-Groningen-NL111). So again it may be advisable for these MSs to avoid implementing 'afforested areas' in regions most vulnerable to dilution issues, and Greece may also need to consider the trade-off between flood regulation benefits and dilution burdens on a region by region basis.

Agroforestry The unweighted scores for agroforestry (Table 4) indicate that there are no regions where the combination of attributes results in the potential benefits and burdens being maximised. The burdens are all very low and although there is some regional variation in the resulting burden (see Fig. 4), it is not significant enough to recommend the avoidance of implementing agroforestry to reduce burdens on dilution.
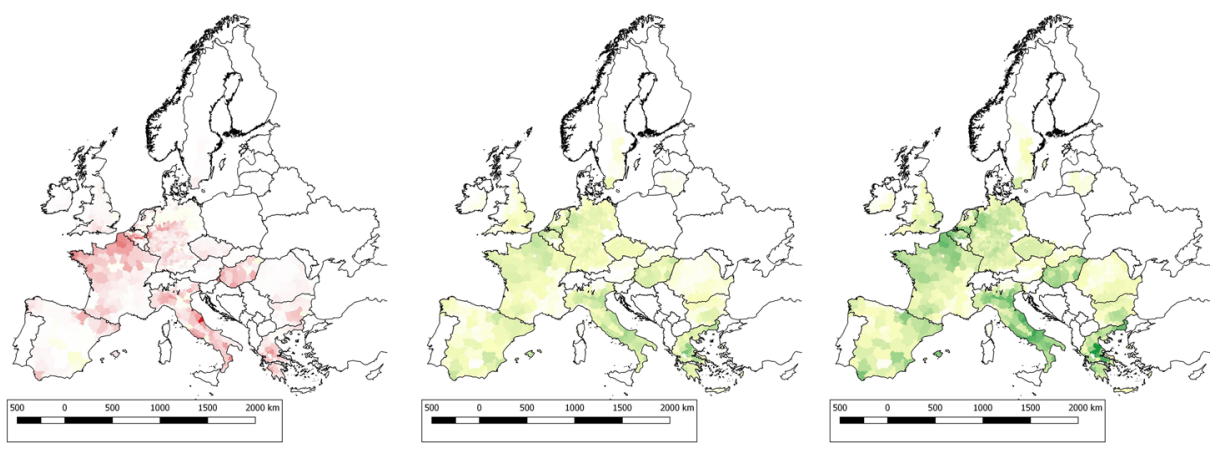

Fig. 7 Catch crops or green cover: dilution 

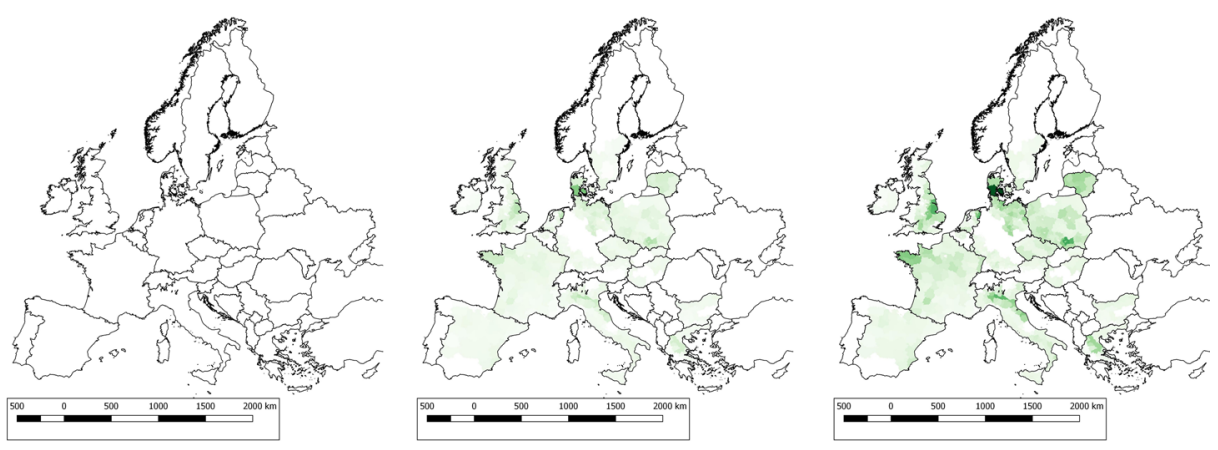

Fig. 8 Ditches: flood regulation

Buffer strips The unweighted scores for buffer strips (Table 4) indicate that there are regions where the combination of attributes means that the potential benefits for both dilution and filtration are high (as indicated by the +78 score) and some regions where the combination of attributes results in low to moderate burden $(-15)$. The Score ${ }_{\mathrm{VW}}$ and $\mathrm{Score}_{\mathrm{VAW}}$ values are significantly lower for the burdens indicating that high vulnerability is not coinciding with the attributes for burdens and/or high proportion of arable land in the region. The benefits are also lower when weighted for vulnerability and area, but remain low to moderate (41 and 16 for dilution and 51 and 25 for filtration). Overall, this indicates there is scope for benefits from buffer strips and only a few locations where the burdens are likely to be minimal or negligible.

The areas with the greatest potential benefits for dilution and filtration from buffer strips include those where vulnerability to dilution and filtration are high, there is low annual rainfall, coarse soils and a high soil hydraulic conductivity for loss of phosphate and pesticides, moderate soil hydraulic conductivity for loss of nitrogen and there is a high proportion of arable land. For dilution (see Fig. 5), this includes northern France, and Belgium, eastern Spain, south and eastern Netherlands, western Germany, north-east and southern Italy, Hungary and eastern Greece. There are some minor differences between the worst and best case scenarios, but notably the worst case scenario results in some minor burdens in northwest Spain, northern Italy and central Germany. For filtration (see Fig. 6), there are very clear benefits in northern France, followed by southern England, northeast Italy and Hungary, with minor benefits across most other regions. In the main, differences between the worst and best case scenarios are minor, although the worst case scenario does result in some minor burdens
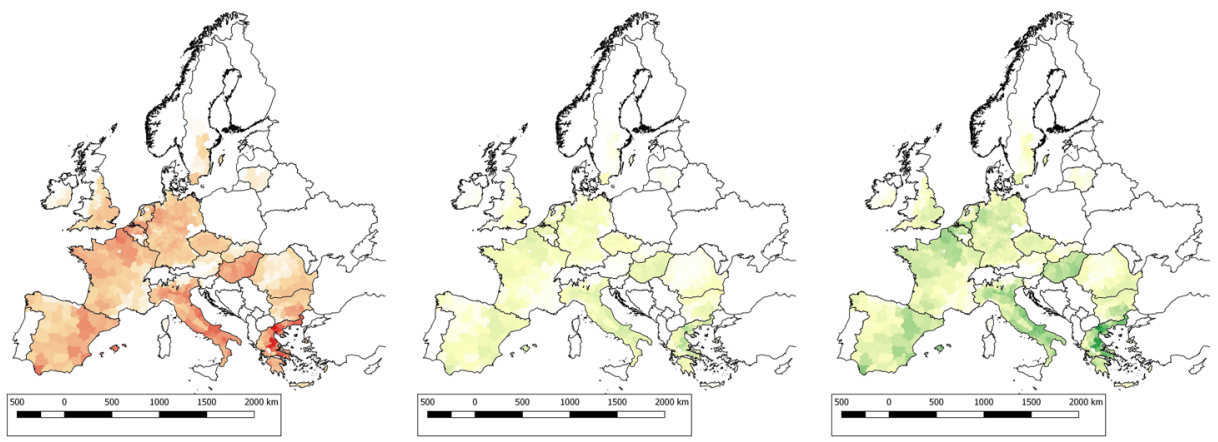

Fig. 9 Ditches: dilution 

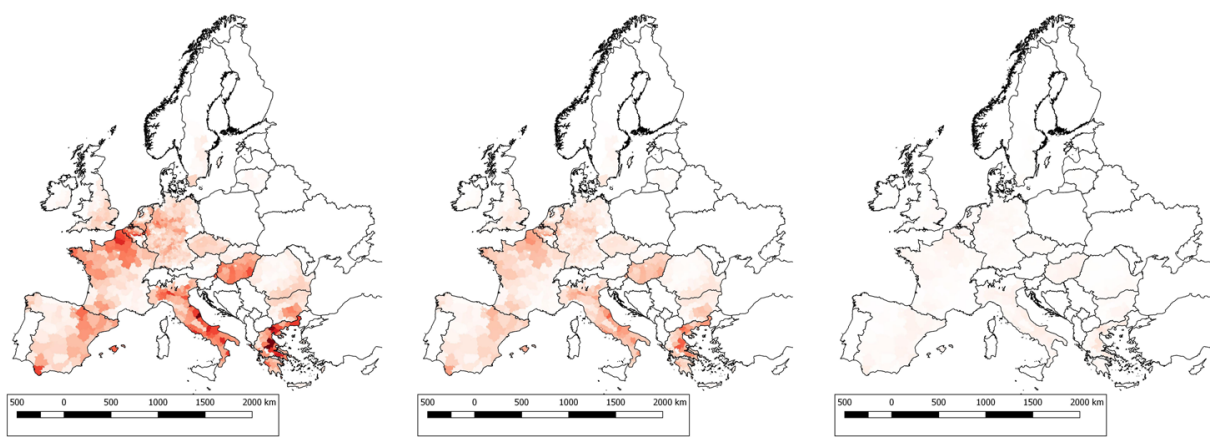

Fig. 10 Fallow land: dilution

in northwest Spain, and in a few regions of central Germany, northern Italy and northern France. Other more geographically localised and/or management factors that influence the benefits/burdens and were unspecified include the width of the buffer strip, vegetation height and density; slope; risk of overland flow becoming concentrated; removal of accumulated pollutants; erosion risk; presence of sub-surface drains; and the depth of impermeable layer beneath buffer strip (Bhattarai et al. 2009; Kay et al. 2009; Krutz et al. 2005; Reichenberger et al. 2007).

There are 15 MS that have not activated the 'buffer strips' EFA. Two of these have been identified as having significant potential for benefits for dilution, i.e. Czech Republic (e.g. Stredocesky kraj-CZ020) and Spain (e.g. Tarragona_ES514). Spain (e.g. Cádiz-ES612) and the Netherlands (e.g. West-Noord-Brabant-NL411) could also achieve minor benefits for filtration.

Catch crops or green cover The unweighted scores for catch crops or green cover (Table 4) indicate that there are regions where the combination of attributes results in moderate potential benefits for dilution $(+36)$ and there are some regions where the worst case would result in a

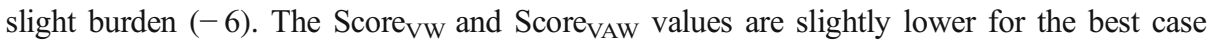
scenario and significantly lower for the worst case scenario indicating that high vulnerability and/or a high proportion of arable land in the region, are only partially coinciding with the attributes for benefits and not coinciding for burdens.
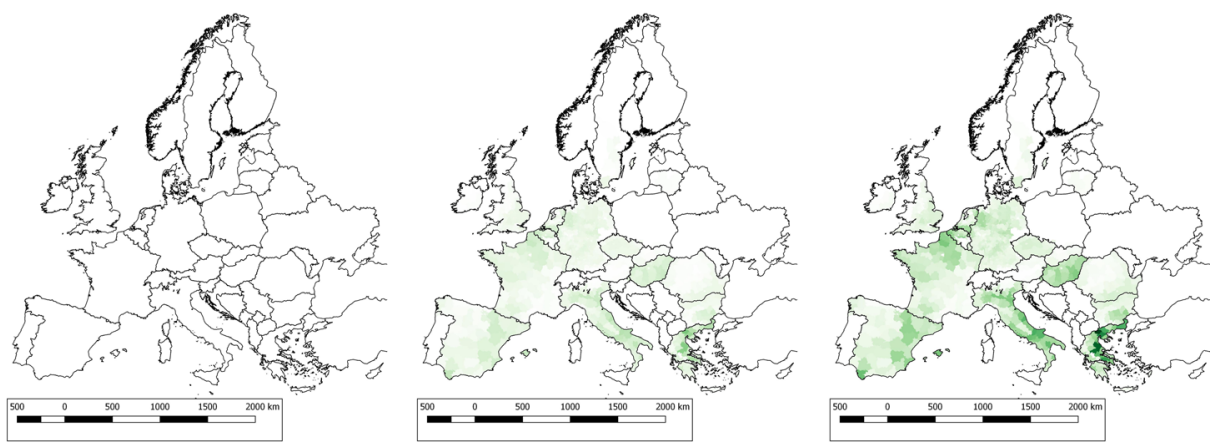

Fig. 11 Hedges or wooded strips: dilution 

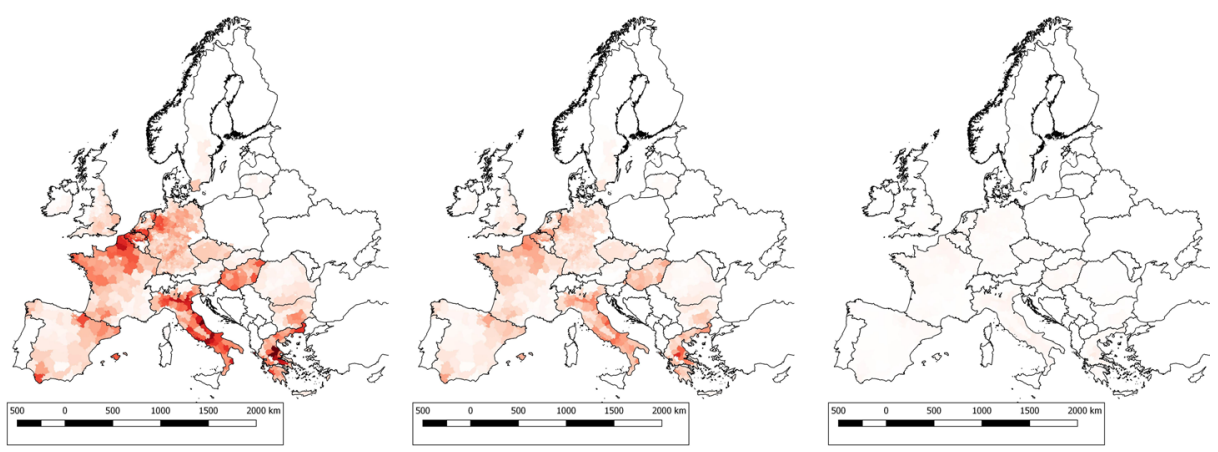

Fig. 12 Nitrogen fixing crops: dilution

The areas with the greatest potential benefits for dilution from catch crops are those where the vulnerability to dilution is high and those which have coarse soils, high annual rainfall (i.e. those where leaching risk is high) and there is a high proportion of arable land. This includes Italy, northeast France, northern Belgium, western Germany, eastern and southwest Spain, Hungary and Greece (see Fig. 7). There are some minor differences between the worst and best case scenarios, with the worst case scenario resulting in minor burdens in northern France, northeast Spain, patches of central and eastern Germany, patches in Italy, Greece and Hungary. Other more geographically localised and/or management factors that influence the benefits/ burdens and were unspecified include slope, with flatter areas reducing the risk of losses via run-off and the catch crop species, with the greatest benefits provided by, for example, Brassica napus (rapeseed) and Hordeum vulgare (barley) and least by Zea spp. (maize) and Vicia sativa (common vetch) (depending on the other factors present) (Dabney et al. 2001; Novara et al. 2011; Ruiz-Colmenero et al. 2011; Shepherd 1999).

There are ten MSs that have not activated the 'catch crops or green cover' EFA. Three of these have been identified as having significant potential for benefits for dilution. These are Italy (e.g. Campobasso-ITF22), Spain (e.g. Cádiz-ES612) and Greece (e.g. Karditsa, Trikala-EL611).

Ditches The unweighted scores for ditches (Table 4) indicate that there are regions where the combination of attributes results in high potential benefit $(+75)$ or moderate burden $(-20)$ for dilution, and the benefit is maximised $(+100)$ for flood regulation. For dilution, the Score $\mathrm{VW}$
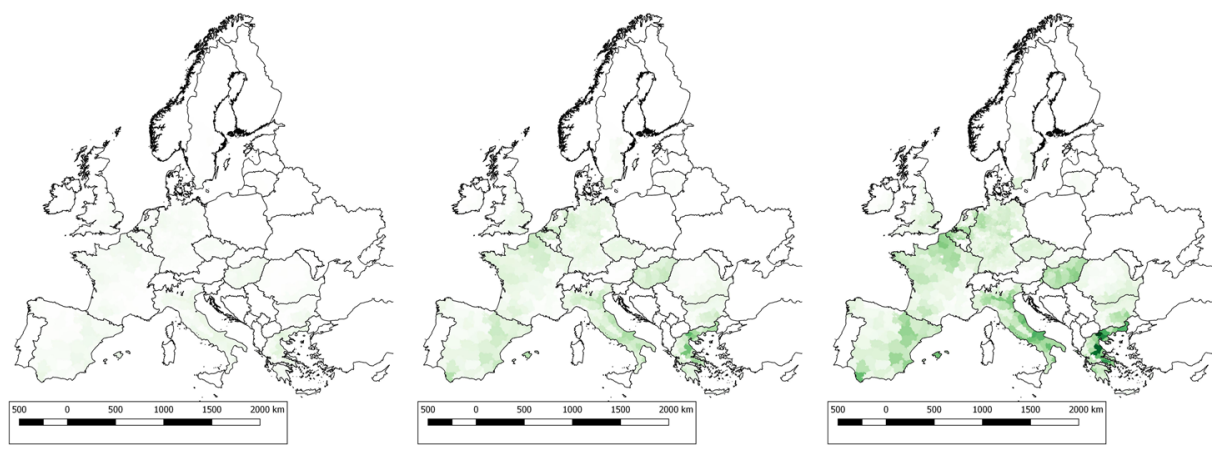

Fig. 13 Ponds: dilution 

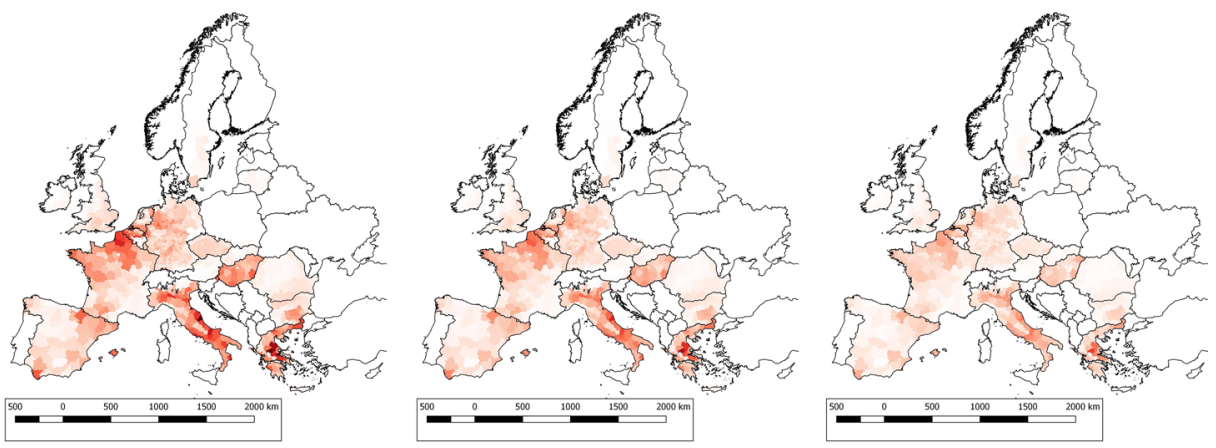

Fig. 14 Short rotation coppice: dilution

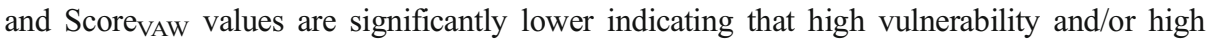
proportion of arable land in the region are not coinciding with the attributes for high benefits or burdens, but they are still moderate and low for the best and worst case scenarios. For flood regulation, there is a greater coincidence with a maximum Score $_{V w}$ value $(+100)$ and a

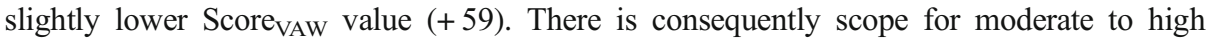
benefits in relation to flood regulation, moderate benefits for dilution and low burdens for dilution.

The areas where ditches have a high benefit for flood regulation are simply those where the vulnerability to flooding is high and there is a high proportion of arable land. This includes central Denmark, eastern England, northwest France, central-northern Italy, central Greece, northeast Germany, southern Poland and Lithuania (see Fig. 8). There are some minor differences between the worst and best case scenarios, with the worst case scenario resulting in no benefits for flood regulation. Areas where ditches have benefits and burdens for dilution relate to the dilution vulnerability in the region and the proportion of arable land. The greatest benefits are in northern France and Belgium, eastern and southwest Spain, south and eastern Netherlands, western Germany, northeast and southern Italy, Hungary, southern Bulgaria and eastern Greece (see Fig. 9). There are some minor differences between the worst and best case scenarios, with the worst case scenario resulting in burdens in northern France, southeast England, eastern and southwest Spain, Germany, Czech Republic, Hungary, southern Romania, Bulgaria and Greece. The worst to best case scenarios are influenced by more geographically localised and/or management factors which have not been specified in this spatial analysis. These factors include disposal of cut weeds (whether they are removed or not), presence of low-grade weirs/small dams in ditch (with sediments removed periodically), the general in-ditch flow rate, the presence of in-ditch vegetation, dredging of ditch sediments, disposal of dredged sediments, time of dredging, whether high sulphate soil additions are used, intermittent periods of ditch drying and whether livestock have access to the ditch bank (Kröger et al. 2014; Needelman et al. 2007; Shore et al. 2015; Smith 2009).

There are 14 MSs that have not activated the 'ditches' EFA. Two of these have been identified as having significant potential for benefits for dilution. These are Spain (e.g. Cádiz-ES612) and Bulgaria (e.g. Yambol-BG343). Consequently, activation of this EFA in these regions may be beneficial. In the case of Bulgaria, the 'ditches' EFA was available in 2015-2016, but has been deactivated in 2017. The reasons for this are unknown, but it should perhaps be reconsidered for activation in the future. A number of MSs also have regions where low burdens in relation to dilution might result from ditches, such as Kilkis (EL523) in Greece. 


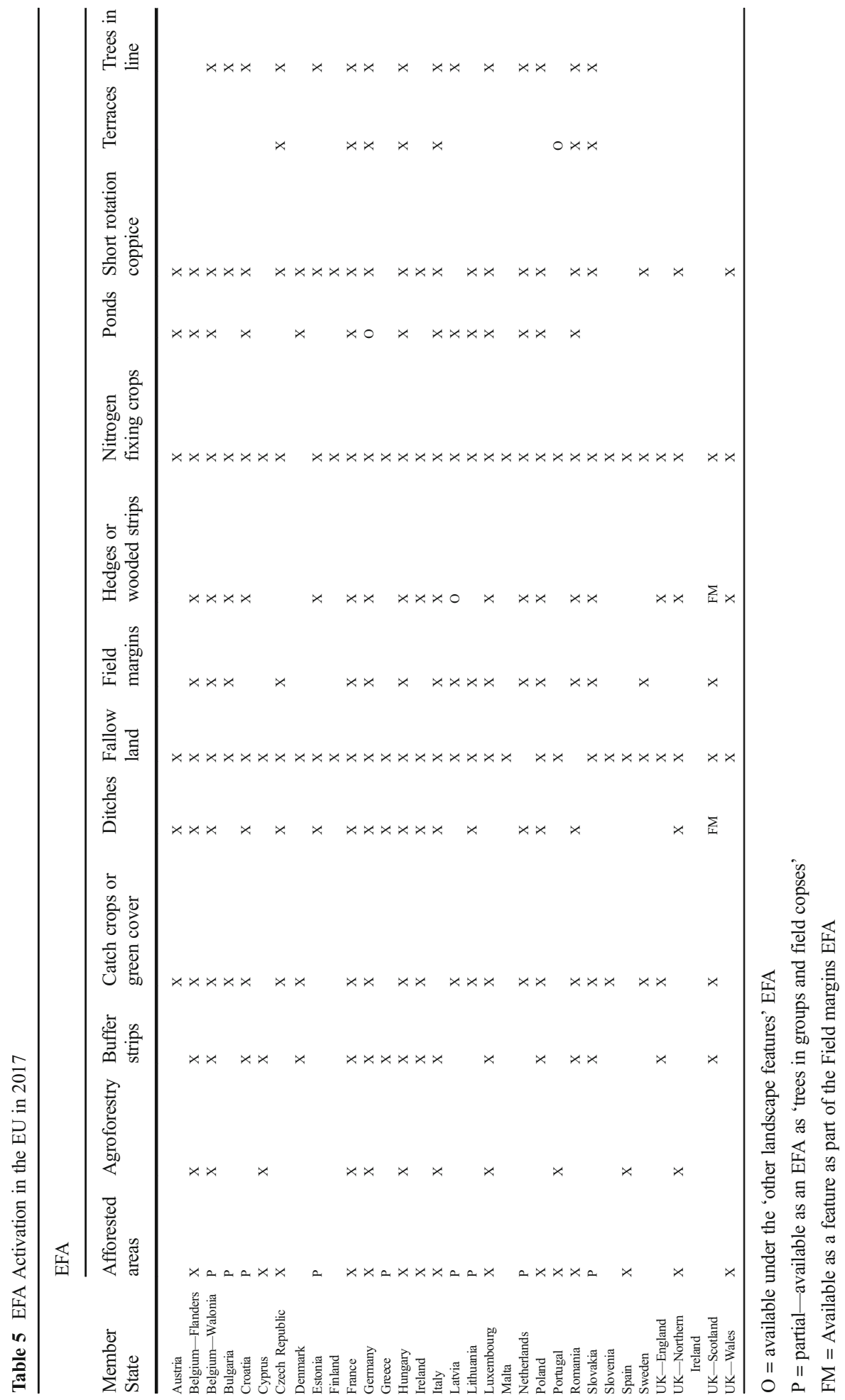


Table 6 Example region impact scores

\begin{tabular}{|c|c|c|c|c|c|c|c|}
\hline \multirow[t]{2}{*}{ EFA and region } & \multirow[t]{2}{*}{ Service } & \multicolumn{2}{|l|}{ Score } & \multicolumn{2}{|c|}{ Score $_{\mathrm{VW}}$} & \multicolumn{2}{|c|}{ Score $_{\text {VAW }}$} \\
\hline & & Worst & Best & Worst & Best & Worst & Best \\
\hline \multicolumn{8}{|l|}{ Afforested areas } \\
\hline Sydjylland (DK032) & Flood regulation & 28 & 81 & 23 & 65 & 16 & 46 \\
\hline Lincolnshire (UKF30) & Flood regulation & 28 & 81 & 11 & 32 & 10 & 29 \\
\hline Larisa (EL612) & Flood regulation & 28 & 81 & 14 & 40 & 7 & 19 \\
\hline Siauliu apskritis (LT006) & Flood regulation & 28 & 81 & 11 & 32 & 7 & 19 \\
\hline Eure-et-Loir (FR242) & Water provision & -81 & -28 & -81 & -28 & -64 & -22 \\
\hline Salzland (DEE0C) & Water provision & -81 & -28 & -81 & -28 & -65 & -23 \\
\hline Bekes (HU332) & Water provision & -81 & -28 & -81 & -28 & -66 & -23 \\
\hline Treviso (ITD34) & Water provision & -86 & -34 & -86 & -34 & -54 & -22 \\
\hline Lubelski (PL314) & Water provision & -81 & -28 & -81 & -28 & -53 & -19 \\
\hline Ialomita (RO315) & Water provision & -81 & -28 & -81 & -28 & -67 & -24 \\
\hline Valladolid (ES418) & Water provision & -81 & -28 & -81 & -28 & -64 & -23 \\
\hline Arr. Ieper (BE253) & Dilution & -70 & -50 & -10 & -7 & -8 & -5 \\
\hline Somme (FR223) & Dilution & -72 & -52 & -10 & -7 & -7 & -5 \\
\hline Emsland (DE949) & Dilution & -80 & -60 & -8 & -6 & -6 & -4 \\
\hline Cremona (ITC4A) & Dilution & -70 & -50 & -8 & -6 & -7 & -5 \\
\hline Teruel (ES242) & Dilution & -70 & -50 & -17 & -12 & -6 & -4 \\
\hline Larisa (EL612) & Dilution & -42 & -22 & -18 & -9 & -8 & -4 \\
\hline Oost-Groningen (NL111) & Dilution & -90 & -70 & -9 & -7 & -8 & -6 \\
\hline \multicolumn{8}{|l|}{ Buffer strips } \\
\hline Stredocesky kraj (CZ020) & Filtration & 8 & 75 & 1 & 7 & 0 & 4 \\
\hline Cádiz (ES612) & Dilution & 1 & 73 & 0 & 21 & 0 & 8 \\
\hline Tarragona (ES514) & Filtration & 5 & 76 & 2 & 33 & 0 & 6 \\
\hline West-Noord-Brabant (NL411) & Dilution & 9 & 76 & 1 & 11 & 1 & 7 \\
\hline \multicolumn{8}{|l|}{ Catch crops or green cover } \\
\hline Campobasso (ITF22) & Dilution & -2 & 35 & 0 & 8 & 0 & 5 \\
\hline Cádiz (ES612) & Dilution & -2 & 28 & 0 & 8 & 0 & 3 \\
\hline Karditsa, Trikala (EL611) & Dilution & -2 & 35 & -1 & 15 & 0 & 7 \\
\hline \multicolumn{8}{|l|}{ Ditches } \\
\hline Cádiz (ES612) & Dilution & -20 & 75 & -6 & 21 & -2 & 8 \\
\hline Yambol (BG343) & Dilution & -20 & 75 & -3 & 11 & -2 & 6 \\
\hline Kilkis (EL523) & Dilution & -20 & 75 & -8 & 32 & -4 & 16 \\
\hline Sydjylland (DK032) & Flood regulation & 0 & 100 & 0 & 80 & 0 & 57 \\
\hline Lincolnshire (UKF30) & Flood regulation & 0 & 100 & 0 & 40 & 0 & 36 \\
\hline \multicolumn{8}{|l|}{ Fallow land } \\
\hline Teleorman (RO317) & Dilution & -22 & -2 & -1 & 0 & -1 & 0 \\
\hline Zeeuwsch-Vlaanderen (NL341) & Dilution & -25 & -2 & -3 & 0 & -2 & 0 \\
\hline Somme (FR223) & Dilution & -31 & -2 & -4 & 0 & -3 & 0 \\
\hline Ascoli Piceno (ITE34) & Dilution & -36 & -2 & -8 & -1 & -4 & 0 \\
\hline Karditsa, Trikala (EL611) & Dilution & -25 & -2 & -10 & -1 & -5 & 0 \\
\hline Bekes (HU332) & Dilution & -27 & -2 & -3 & 0 & -3 & 0 \\
\hline \multicolumn{8}{|l|}{ Hedges or wooded strips } \\
\hline Cádiz (ES612) & Dilution & 0 & 100 & 0 & 28 & 0 & 11 \\
\hline Kilkis (EL523) & Dilution & 0 & 100 & 0 & 42 & 0 & 21 \\
\hline \multicolumn{8}{|l|}{ Nitrogen fixing crops } \\
\hline Stara Zaogora (BG344) & Dilution & -26 & -1 & -5 & 0 & -2 & 0 \\
\hline Somme (FR223) & Dilution & -35 & -2 & -5 & 0 & -4 & 0 \\
\hline Steinfurt (DEA37) & Dilution & -36 & -2 & -4 & 0 & -3 & 0 \\
\hline Larisa (EL612) & Dilution & -23 & -1 & -10 & -1 & -5 & 0 \\
\hline Bekes (HU332) & Dilution & -26 & -1 & -3 & 0 & -3 & 0 \\
\hline Ascoli Piceno (ITE34) & Dilution & -38 & -2 & -9 & 0 & -5 & 0 \\
\hline Navarra (ES220) & Dilution & -34 & -2 & -8 & 0 & -3 & 0 \\
\hline \multicolumn{8}{|l|}{ Ponds } \\
\hline Kilkis (EL523) & Dilution & 14 & 94 & 6 & 40 & 3 & 20 \\
\hline Zaragosa (ES243) & Dilution & 14 & 94 & 3 & 17 & 1 & 8 \\
\hline Yambol (BG343) & Dilution & 14 & 94 & 2 & 14 & 1 & 8 \\
\hline
\end{tabular}


However, it should be noted that the worst case values, as explained above, would only be realised under specific local and/or management factors.

Two MSs that have not activated the 'ditches' EFA have been identified as having significant potential for benefits for flood regulation. These are Denmark (e.g. SydjyllandDK032) and UK-England (e.g. Lincolnshire-UKF30).

Fallow land The unweighted scores for fallow land (Table 4) indicate that there are regions where the combination of attributes results in a moderate potential burden $(-36)$ for dilution. The Score $_{\mathrm{VW}}$ and Score $_{\mathrm{VAW}}$ values are lower indicating that high vulnerability and/or a high proportion of arable land in the region are not coinciding with the attributes for high burdens.

The areas with the greatest potential burdens for dilution from fallow land are those where the vulnerability to dilution is high, which have coarse soils, high annual rainfall (i.e. those where leaching or soil erosion risk is high) and where there is a high proportion of arable land. This includes northern France, eastern and southern Italy, Greece, Hungary, eastern and southwest Spain, central Germany and southern Bulgaria (see Fig. 10). There is only a small difference between the worst and best case scenario, with the best case having no burdens. Other more geographically localised and/or management factors which will affect the benefits/ burdens and were unspecified are ground cover and slope, with the worst case scenario being coarse soils, high rainfall, bare soil and steep slopes.

Only the Netherlands and Romania have not activated the 'fallow land' EFA. Under a worst case scenario, there is some potential for low burdens in both Romania (e.g. TeleormanRO317) and the Netherlands (e.g. Zeeuwsch-Vlaanderen-NL341), but these are low values and thus are not sufficient to recommend avoiding fallow land (and with no benefits for dilution, there is no incentive activate this EFA) in these MSs.

For those MSs that have activated fallow land, northern France, eastern Italy and Greece and Hungary have regions where the worst case scenario could result in slightly higher burdens. For example, regions such as Somme (FR223), Ascoli Piceno (ITE34), Karditsa, Trikala (EL611) and Bekes (HU332) should perhaps avoid implementing fallow land with bare soil on steep slopes.

Hedges or wooded strips The unweighted scores for hedges or wooded strips (Table 4) indicate that there are regions where the combination of attributes results in a maximum potential benefit $(+100)$ for dilution. The Score $\mathrm{VW}_{\mathrm{VW}}$ and Score $_{\mathrm{VAW}}$ values are lower, but this relates to the vulnerability score and the proportion of arable land in the region. This includes northern France and Belgium, eastern and southwest Spain, south and eastern Netherlands, western Germany, northeast and southern Italy, Hungary and eastern Greece (see Fig. 11). There are some minor differences between the worst and best case scenarios, with the worst case scenario providing no benefits. The unspecified attributes that affect the performance of hedges with regard to dilution (other than vulnerability) are more localised and management factors, including the hedge height and porosity, whether pesticides are applied upwind and whether water bodies are downwind of the hedge (Hagen and Skidmore 1971; Rider 1952; Schwartz et al. 1995; Ucar and Hall 2001). These factors account for the range in performance from worst (0) to best case (21).

There are 13 MSs that have not activated the 'hedges or wooded strips' or 'trees in a line' EFAs. Two of these have been identified as having significant potential for benefits in relation to dilution. These are Spain (e.g. Cádiz_ES612) and Greece (e.g. Kilkis_EL523). In these countries, it is anticipated that trees in a line (i.e. shelterbelts) would be the EFA to be activated as hedgerows are a less traditional feature in these countries. 
Nitrogen fixing crops The unweighted scores for nitrogen fixing crops (Table 4) indicate that there are regions where the combination of attributes results in a moderate potential burden for dilution $(-41)$. The Score $_{\mathrm{VW}}$ and Score $\mathrm{VAW}_{\mathrm{W}}$ values are lower indicating a high vulnerability and/or high proportion of arable land are not coinciding with the attributes for high burdens.

The areas with the greatest potential burdens for dilution from nitrogen fixing crops are those where the vulnerability to dilution is high, those which have coarse soils and high annual rainfall (i.e. those where leaching risk is high) and where there is a high proportion of arable land. This includes northern France, eastern and southern Italy, Greece, Hungary, eastern and southwest Spain, western Germany and southern Bulgaria (see Fig. 12). There is only a small difference between the worst and best case scenario, with the best case having no burdens. Other more geographically localised and/or management factors which will affect the benefit/burden and were unspecified are the crop species (which affects ground cover, and thus run-off and leaching losses) and slope, with the worst case scenario being coarse soils, high rainfall, steep slopes and species such as Galega spp. (Goat's rue), Pisum spp. (Pea), Vicia faba (Faba bean), Arachis spp. (Pinut) and Hedysarum coronarium (French honeysuckle) (Entrup and Stemann 1990; Jensen et al. 2010; Justus and Köpke 1995).

All MSs except for Denmark have activated the 'nitrogen fixing crops' EFA. There seems to be little scope for burdens in Denmark, so this EFA could be implemented for other benefits without incurring a burden in relation to dilution.

Six MSs have activated the 'nitrogen fixing crops' EFA and have scope for dilution burdens. These are Bulgaria (e.g. Stara Zaogora-BG344), France (e.g. Somme-FR223), Germany (e.g. Steinfurt-DEA37), Greece (e.g. Larisa-EL612), Hungary (e.g. BekesHU332), Italy (e.g. Ascoli Piceno-ITE34) and Spain (e.g. Navarra-ES220). In these regions, the species mentioned above should perhaps be avoided in high-risk areas (i.e. coarse soils, high annual rainfall and steep slopes).

Ponds The unweighted scores for ponds (Table 4) indicate that there are regions where the combination of attributes results in a high potential benefit for dilution (+97). The Score $\mathrm{Vw}$ and Score $_{\mathrm{VAW}}$ values are significantly lower, but are still moderate (51 and 20). Overall, this indicates that there is scope for dilution benefits from ponds.

The areas with the greatest potential for benefits are those where the vulnerability to dilution is high, those which have a high annual temperature and there is a high proportion of arable land. This includes northern France, eastern and southern Italy, Greece, Hungary, eastern and southwest Spain, western Germany and southern Bulgaria (see Fig. 13). There is only a small difference between the worst and best case scenario, with the worst case having no benefits. Other more localised and management factors which will affect the benefit/burden and were unspecified are the pond size and average retention time, whether it is part of series of ponds and whether sediments are removed by dredging (Braskerud 2002a, b; Céréghino et al. 2014; IGER 2002; Ockenden et al. 2014).

Seventeen MSs have not activated the 'ponds' EFA. Three of these have been identified as having significant potential for benefits on dilution. These are Greece (e.g. Kilkis-EL523), Spain (e.g. Zaragosa -ES243) and Bulgaria (e.g. Yambol-BG343). Consequently, activation of this EFA in these regions may be beneficial. In the case of Bulgaria, the ponds EFA was available in 2015-2016, but has been deactivated in 2017. The reasons for this are unknown, but it should perhaps be considered for reactivation in the future. 
Short rotation coppice The unweighted scores for short rotation coppice (Table 4) indicate that there are no regions where the combination of attributes means that potential benefits or burdens are maximised, there are just very low burdens. Although there are some regional variations within this slight burden (see Fig. 14), it is not significant enough to recommend the avoidance of implementing short rotation coppice to reduce dilution burdens.

\subsection{Limitations and wider perspectives}

This study has brought together the outputs from two continental-scale projects, both of which synthesised a substantial amount of scientific data and information. In some respects, it has been an exercise in the conversion of scientific knowledge into a format that can aid pragmatic decision making. This conversion process inherently involves aggregation and simplification and the application of novel processes and techniques. Consequently, it is important to acknowledge some of the weaknesses in the approach and any limitations on the findings of this study.

Firstly, it is important to acknowledge that the assessments have been made based on a knowledge base of existing evidence of the potential impact of EFAs, and this is not complete for all ecosystem services across all the EFAs. Consequently, there may be benefits and burdens for some ecosystem services from some of the EFAs explored in this study, which have not been highlighted in this analysis. For example, afforested areas are the only EFA that has been examined with respect to impacts on water provision. Other EFAs, such as agroforestry, ditches, hedges, ponds and short rotation coppice, may also have an impact. However, the knowledge base (Tzilivakis et al. 2015b) that underpins the indicator framework (Tzilivakis et al. 2016) is based on the weight of evidence that was available at the time, and there was a lack of scientific evidence specifically exploring the impact of these EFAs in relation to water provision. Similarly, only afforested areas and ditches have been examined with respect to impacts on flood regulation. Many other EFAs could also potentially affect hydrological processes and thus flood regulation, but again evidence associating (and quantifying) the effect of specific EFAs was lacking. This is not a new phenomenon, as all environmental assessments are made based on the most established and relevant scientific understanding available at the time. Scientific knowledge is evolving and growing all the time; consequently, efforts are ongoing to plug gaps in the knowledge base that underpins the EFA calculator, and as the science improves, the assessments made within the tool should reflect this.

It is important to acknowledge that the spatial analysis presented herein is a relatively broad-brush approach and that any benefits or burdens identified for a region do not mean this will definitely occur should those EFAs be implemented on any farm within the region. Specific benefits and burdens will depend on the details of their implementation on each farm within each region, e.g. buffer strips being located in the right places to be most effective in a catchment. The analysis presented herein does account for this to some extent by presenting the worst and best case scenarios (which account for unspecified parameters), but it is likely there will be greater variability.

In relation to the last point, it is also important to acknowledge that no account is taken of the performance of an EFA in a region in relation to a baseline. The analysis is simply highlighting the potential benefits and burdens should the EFA be implemented on 5\% of the arable land within the region. The EFA policy only requires that an area of the farm that is equivalent to $5 \%$ of arable land area is declared as EFA. This may not necessarily require the creation of new 
EFAs, as EFAs covering 5\% may already exist. The baseline situation could be accounted for within the spatial analysis by adjusting the area weighting using data on existing EFA declaration or using data such as the distribution of semi-natural vegetation in agricultural land (as done by Angileri et al. 2017). However, in this instance, the study is examining potential future vulnerabilities and the need to increase capacity within a region to cope with climate change. Therefore, the results presented herein should be interpreted as a need to increase certain EFAs in order gain the benefits (or avoiding certain EFAs to decrease burdens).

It is also important to reiterate that the indicator framework used (Tzilivakis et al. 2016), and thus the analysis presented, is one that identifies the relative performance of an EFA and does not quantify actual benefits or burdens for ecosystem services. Quantification of ecosystem services requires more sophisticated techniques, many of which do not exist for such broad-scale analyses (Baveye 2017; Maes et al. 2016). Efforts are being made to develop such techniques, such as those that have emerged from the Quantification of Ecological Services for Sustainable Agriculture project (QuESSA 2017). Some of these have been incorporated into the latest version of the EFA calculator, but these are only available for a limited number of ecosystem services, including pollination, pest control, soil erosion, carbon and aesthetics. As such techniques evolve and develop, a similar analysis to the one presented herein could be undertaken using these techniques, and could liberate additional information that could aid decision making and the selection and implementation of EFAs that maximise benefits and minimise burdens for ecosystem services under current and future climatic scenarios.

This study has explored the potential benefits and burdens of EFAs on water-related ecosystem services vulnerable to climate change. It is important to remember that the EFAs examined in this study (and those not examined) also have other benefits and burdens which will influence decisions with regard to their promotion (via policy) and uptake on the ground. There can be numerous effects and impacts to consider, for example climate regulation (greenhouse gas emissions, including above and below ground carbon), soil erosion, pollination, pest control, aesthetic and other cultural services and biodiversity. Some of these could be explored using the spatial analysis presented herein, but many will depend on more localised variables and management factors for which georeferenced spatial data do not exist. Should this data for these factors become available, then these could be analysed in the same way, extending the assessment to include more ecosystem services and EFAs, and thus providing a more holistic perspective.

It is important that other benefits and burdens are taken into account in the decision making processes associated with their promotion, uptake and implementation. This will involve identifying where there are synergies and trade-offs to be taken into account. The spatial analysis presented in this study can support these decision making processes by identifying regions where the greatest benefits and burdens might occur in the event of climate change projections being realised. For example, afforested areas have the potential to provide benefits for flood regulation and burdens for water provision and dilution. Under the right circumstances, they can also provide benefits for numerous wildlife species, climate regulation (via carbon sequestration), pollination and aesthetic services. The synergies and trade-offs between these benefits and burdens will need to be considered within each region when considering the implementation of EFAs. As such, the spatial analysis presented herein can contribute towards understanding such synergies and trade-offs in the context of future vulnerabilities and threats from climate change.

This study has explored the potential impact on ecosystem services from a number of land uses and landscape features in the context of Europe and its land use policies in the light of 
projected changes in climate in the future. Other continents and countries around the world face similar challenges (Chang and Bonnette 2016; Fu et al. 2017; Malinga et al. 2015; Overbeck et al. 2015; Rodríguez-Echeverry et al. 2018; Tolessa et al. 2017), so there is a need for tools and techniques to aid policy assessment and development. For example, Tolessa et al. (2017) utilised GIS techniques to estimate changes in ecosystem services over 40-year period as a consequence of land use change in the central highlands of Ethiopia. This study highlighted the impact of Ethiopian land use policies during this period and thus can be used to adapt policies towards sustaining important ecosystem services. Similarly, RodríguezEcheverry et al. (2018) adopted a spatial approach to assess the impact of land use change ecosystem services from Chilean temperate forests and identified that losses in habitat and diversity are having detrimental effects on soil erosion and water supply. Fu et al. (2017) also used a spatial approach to assess the effects of land use and climate change on ecosystem services in central Asia's arid regions and propose a number of policy responses to sustain ecosystem services. All these studies attempt to take into account land use, ecosystem service provision and vulnerability to climate change. An important element amongst them all is the utilisation and tailoring of appropriate measures and indicators in the regions being studied. The study presented herein demonstrates how an indicator framework can be developed based on the latest knowledge of the effects and impacts of land use and then applied in the context of climate change vulnerability using spatial techniques. This 'generic' concept could be applied elsewhere in the world and thus help spatially target mitigation and adaptation policy interventions based on current knowledge and understanding in any given region.

\subsection{Conclusions}

There is little doubt that climate change and its consequent effects and impacts pose a great challenge to society, thus there is a need for robust mitigation and adaptation strategies and policies. Understanding the threats and vulnerabilities is a key aspect to tackle this challenge. Another key aspect is to determine the actions that will minimise any negative effects and impacts. This applies to all industry sectors, including rural land management, and applies to both policy makers and managers on the ground. It is important that relevant stakeholders have access to reliable information, data and analysis that will aid decision making on what are often complex topics. This often involves processing a substantial amount of complex data and information and presenting and interpreting it in a form to support decision making processes.

This study has used the continent of Europe as example to explore the challenges involved in assessing the benefits and burdens of land use policies on water-related ecosystem services that are vulnerable to climate change. Many of these are common to other regions of the world, for example water provision/supply in California, USA (Byrd et al. 2015), Chile (RodríguezEcheverry et al. 2018) and Ethiopia (Tolessa et al. 2017); water regulation and flooding in China (Ouyang et al. 2016) and the USA (Blumstein and Thompson 2015); and water quality in China (Gao et al. 2017) and Japan (Fan and Shibata 2015). Consequently, the study presented in this paper has global relevance. Many of the land uses and landscape features explored in this study exist in other regions of the world. The effects and impacts will vary with location, as they do in Europe, but under similar circumstances, similar benefits and burdens may arise. Where circumstances are different, the approach presented in this paper of combining pertinent indicators, spatial data and vulnerability assessments could be applied to other regions and continents to aid the development of mitigation and adaptation strategies and policies for land use and ecosystem services. 
This study combined the outputs from two continental-scale projects to provide a means to identify European regions where EFAs may help increase the capacity of water-related ecosystem services in areas where they are vulnerable due to climate change. Six EFAs have been identified which have not been activated in some MSs, but which have the potential to provide benefits. These include afforested areas for flood regulation in Denmark, England, Greece and Lithuania; buffer strips for dilution and filtration in the Czech Republic, Netherlands and Spain; catch crops or green cover for dilution in Greece, Italy and Spain; ditches for dilution in Bulgaria and Spain and for flood regulation in Denmark and England; trees in a line (hedges) for dilution in Greece and Spain; and ponds for dilution in Bulgaria, Greece and Spain. It is recommended that these MSs consider activating these EFAs in the future. Eleven Member States have also been identified which have regions where some EFAs should perhaps be avoided, due to potential burdens on vulnerable ecosystem services. These include afforested areas for water provision in some regions in France, Germany, Hungary, Italy, Poland, Romania and Spain, and for dilution in some regions in Belgium, France, Germany, Italy, Spain, Greece and the Netherlands; fallow land for dilution in some regions in the Netherlands, Romania, France, Italy, Greece and Hungary; and nitrogen fixing crops for dilution in some regions in Bulgaria, France, Germany, Greece, Hungary, Italy and Spain.

Current European policy does not require that new EFAs be created to meet the 5\% arable area threshold for farms, as existing land use and landscape features can be declared as EFAs. This is still a positive policy as it aims to maintain these areas for the future. However, given the challenges that lie ahead with respect to climate change, there is a growing need to increase, rather than just maintain, the capacity of landscapes to perform the ecosystem services that society relies on, such as water provision, flood regulation and the water purifying services of filtration and dilution. As such, EFAs and/or other land management policies need to encourage this increase in capacity, especially in the most vulnerable regions.

It will also be important to ensure that there are demonstrable benefits from the implementation of EFAs or other interventions. The impact of land use policies on ecosystem services should be monitored to ensure expected outcomes are realised, and when they are not realised evidence on the reasons for this should be gathered. This will generate new scientific data, evidence and understanding that can be used to improve the knowledge base, improve the tools available to aid future decision making and consequently make progress towards more sustainable and resilient land use that delivers the ecosystem services society requires.

Acknowledgements The two projects which form the foundation for this study were funded by European Commission's Directorate General for Climate Action (Ref. 071201/2011/609681/SER/CLIMA.A.2) and the Joint Research Centre (JRC), Ispra, Italy (Ref. JRC/IPR/2014/H.4/0022/NC). The Commission's original support is gratefully acknowledged. The work to develop the batch processing system for the EFA calculator was funded by the JRC (Ref. Ares(2017)1119080 - 02/03/2017). The analysis work undertaken for this study was not funded by the Commission. The opinions expressed herein are those of the authors and not necessarily those of the original funding bodies.

Open Access This article is distributed under the terms of the Creative Commons Attribution 4.0 International License (http://creativecommons.org/licenses/by/4.0/), which permits unrestricted use, distribution, and reproduction in any medium, provided you give appropriate credit to the original author(s) and the source, provide a link to the Creative Commons license, and indicate if changes were made. 


\section{References}

AERU (2013) Optimal design of climate change policies through the EU's rural development policy. Final report for project 071201/2011/609681/SER/CLIMA.A.2. Prepared by the agriculture and environment research unit (AERU), university Hertfordshire, UK. DG climate action, European Commission, Brussels

AERU (2014) Optimal strategies for climate change action in rural areas (OSCAR). Software website. http://sitem.herts.ac.uk/aeru/oscar/. Accessed: 8 January 2018

AERU (2017) Ecological focus areas (EFAs) calculator software. Agriculture and Environment Research Unit (AERU), University of Hertfordshire, United Kingdom. http://sitem.herts.ac.uk/aeru/efa/. Accessed: 8 January 2018

Allen A, Chapman D (2001) Impacts of afforestation on groundwater resources and quality. Hydrogeol J 9(4): 390-400. https://doi.org/10.1007/s100400100148

Angileri V, Fasbender D, Van Eupen C, Tzilivakis J, Warner DJ, Devos W, Loudjani P, Paracchini ML, Terres JM (2017) Using the ecological focus area (EFA) calculator to assess the potential impact of EFA implementation on biodiversity and ecosystem services. Technical report by the Joint Research Centre (JRC). EUR 28311 EN. doi:https://doi.org/10.2788/20041

Bastrup-Birk A, Gundersen P (2004) Water quality improvements from afforestation in an agricultural catchment in Denmark illustrated with the INCA model. Hydrol Earth Syst Sci 8(4):764-777. https://doi.org/10.5194 hess-8-764-2004

Baveye PC (2017) Quantification of ecosystem services: beyond all the "guesstimates", how do we get real data? Ecosyst Serv 24:47-49. https://doi.org/10.1016/j.ecoser.2017.02.006

Bhattarai R, Kalita PK, Patel MK (2009) Nutrient transport through a vegetative filter strip with subsurface drainage. J Environ Manag 90(5):1868-1876. https://doi.org/10.1016/j.jenvman.2008.12.010

Blumstein M, Thompson JR (2015) Land-use impacts on the quantity and configuration of ecosystem service provisioning in Massachusetts, USA. J Appl Ecol 52(4):1009-1019. https://doi.org/10.1111/13652664.12444

Brack W, Altenburger R, Schüürmann G, Krauss M, López Herráez D, van Gils J, Slobodnik J, Munthe J, Gawlik BM, van Wezel A, Schriks M, Hollender J, Tollefsen KE, Mekenyan O, Dimitrov S, Bunke D, Cousins I, Posthuma L, van den Brink PJ, de Alda ML, Barceló D, Faust M, Kortenkamp A, Scrimshaw M, Ignatova S, Engelen G, Massmann G, Lemkine G, Teodorovic I, Walz KH, Dulio V, Jonker MTO, Jäger F, Chipman K, Falciani F, Liska I, Rooke D, Zhang X, Hollert H, Vrana B, Hilscherova K, Kramer K, Neumann S, Hammerbacher R, Backhaus T, Mack J, Segner H, Escher B, de Aragão Umbuzeiro G (2015) The SOLUTIONS project: challenges and responses for present and future emerging pollutants in land and water resources management. Sci Total Environ 503-504:22-31. https://doi.org/10.1016/j. scitotenv.2014.05.143

Braskerud BC (2002a) Factors affecting nitrogen retention in small constructed wetlands treating agricultural non-point source pollution. Ecol Eng 18(3):351-370. https://doi.org/10.1016/S0925-8574(01)00099-4

Braskerud BC (2002b) Factors affecting phosphorus retention in small constructed wetlands treating agricultural non-point source pollution. Ecol Eng 19(1):41-61. https://doi.org/10.1016/S0925-8574(02)00014-9

Byrd KB, Flint LE, Alvarez P, Casey CF, Sleeter BM, Soulard CE, Flint AL, Sohl TL (2015) Integrated climate and land use change scenarios for California rangeland ecosystem services: wildlife habitat, soil carbon, and water supply. Landsc Ecol 30(4):729-750. https://doi.org/10.1007/s10980-015-0159-7

Céréghino R, Vickery JA, Marshall EJP (2014) The ecological role of ponds in a changing world. Hydrobiologia 723(1):1-6. https://doi.org/10.1007/s10750-013-1719-y

Chamberlain DE, Fuller RJ, Bunce RGH, Duckworth JC, Shrubb M (2000) Changes in the abundance of farmland birds in relation to the timing of agricultural intensification in England and Wales. J Appl Ecol 37(5):771-788. https://doi.org/10.1046/j.1365-2664.2000.00548.x

Chang H, Bonnette MR (2016) Climate change and water-related ecosystem services: impacts of drought in California, USA. Ecosyst Health Sustain 2(12):e01254:1-19. https://doi.org/10.1002/ehs2.1254

Ciscar JC, Iglesias A, Feyen L, Goodess CM, Szabó L, Christensen OB, Nicholls R, Amelung B, Watkiss P, Bosello F, Dankers R, Garrote L, Hunt A, Horrocks L, Moneo M, Moreno A, Pye S, Quiroga S, van Regemorter D, Richards J, Roson R, Soria A (2009) Climate change impacts in Europe. Final report of the PESETA research project. European Commission, Joint Research Centre, EUR 24093 EN

Climate Research Unit (2017) Average Annual Temperature. University of East Anglia, UK. https://nelson.wisc. edu/sage/data-and-models/atlas/data.php?incdataset=Average Annual Temperature. Accessed: 8 January 2018

Cresswell JE (2010) A meta-analysis of experiments testing the effects of a neonicotinoid insecticide (imidacloprid) on honey bees. Ecotoxicology 20(1):149-157. https://doi.org/10.1007/s10646-010-0566-0

Dabney SM, Delgado JA, Reeves D (2001) Using winter cover crops to improve soil and water quality. Commun Soil Sci Plant Anal 32(7-8):1221-1250. https://doi.org/10.1081/CSS-100104110 
Donald PF, Green RE, Heath MF (2001) Agricultural intensification and the collapse of Europe's farmland bird populations. Proc R Soc Lond B Biol Sci 268(1462):25-30. https://doi.org/10.1098/rspb.2000.1325

Dunford RW, Smith AC, Harrison PA, Hanganu D (2015) Ecosystem service provision in a changing Europe: adapting to the impacts of combined climate and socio-economic change. Landsc Ecol 30(3):443-461. https://doi.org/10.1007/s10980-014-0148-2

EC (2013a) Regulation (EU) No 1305/2013 of the European Parliament and of the Council of 17 December 2013 on support for rural development by the European Agricultural Fund for Rural Development (EAFRD) and repealing Council Regulation (EC) No 1698/2005. Official Journal of the European Union L 347, 20/12/ 2013, pp. 0487-0548. European Commission (EC)

EC (2013b) Regulation (EU) No 1306/2013 of the European Parliament and of the Council of 17 December 2013 on the financing, management and monitoring of the common agricultural policy and repealing Council Regulations (EEC) No 352/78, (EC) No 165/94, (EC) No 2799/98, (EC) No 814/2000, (EC) No 1290/2005 and (EC) No 485/2008. Official Journal of the European Union L 347, 20/12/2013, pp. 0549-0607. European Commission (EC)

EC (2013c) Regulation (EU) No 1307/2013 of the European Parliament and of the Council of 17 December 2013 establishing rules for direct payments to farmers under support schemes within the framework of the common agricultural policy and repealing Council Regulation (EC) No 637/2008 and Council Regulation (EC) No 73/2009. Official Journal of the European Union L 347, 20/12/2013, pp. 0608-0670. European Commission (EC)

EC (2013d) Regulation (EU) No 1308/2013 of the European Parliament and of the Council of 17 December 2013 establishing a common organisation of the markets in agricultural products and repealing Council Regulations (EEC) No 922/72, (EEC) No 234/79, (EC) No 1037/2001 and (EC) No 1234/2007. Official Journal of the European Union L 347, 20/12/2013, pp. 0671-0854. European Commission (EC)

EEA (2009) Looking back on looking forward: a review of evaluative scenario literature. European Environment Agency (EEA) ISBN 978-92-9167-992-8

EEA (2011) BLOSSOM - bridging long-term scenario and strategy analysis: organisation and methods. A crosscountry analysis. European Environment Agency (EEA). ISBN 978-92-9213-209-5. doi:https://doi. org/10.2800/76903

EEA (2014) Percentage decline (per NUTS 3 area) of arable land area due to land take by economic site and infrastructure development between 2000 and 2006. European Environment Agency (EEA). https://www. eea.europa.eu/data-and-maps/figures/arable-land-with-average-productivity. Accessed: 8 January 2018

EEA (2017) Exceedance of critical loads of acidity. European Environment Agency (EEA). https://www.eea. europa.eu/data-and-maps/figures/exceedance-of-critital-loads-of-acidity. Accessed: 8 January 2018

Entrup NL, Stemann G (1990) Field beans: undersowing solves nitrate problems. DLG Mitteilungen 105(7): 276-277

ESDAC (2017a) Global spatial layers for estimating soil GHG emissions from indirect land use changes (ILUC) due to the production of biofuels. European soil data Centre (ESDAC), European Commission, Joint Research Centre (JRC). http://esdac.jrc.ec.europa.eu/content/global-spatial-layers-estimating-soil-ghgemissions-indirect-land-use-changesiluc-due. Accessed: 8 January 2018

ESDAC (2017b) Maps of indicators of soil hydraulic properties for Europe. European Soil Data Centre (ESDAC), European Commission, Joint Research Centre (JRC). http://esdac.jrc.ec.europa. eu/content/maps-indicators-soil-hydraulic-properties-europe. Accessed: 8 January 2018

ESDAC (2017c) Maps of the storing and filtering capacity of soils in Europe. European soil data Centre (ESDAC), European Commission, Joint Research Centre (JRC). http://esdac.jrc.ec.europa. eu/content/maps-storing-and-filtering-capacity-soils-europe. Accessed: 8 January 2018

ESDAC (2017d) Soil erosion by wind. European Soil Data Centre (ESDAC), European Commission, Joint Research Centre (JRC). http://esdac.jrc.ec.europa.eu/content/Soil_erosion_by_wind. Accessed: 8 January 2018

Fan M, Shibata H (2015) Simulation of watershed hydrology and stream water quality under land use and climate change scenarios in Teshio River watershed, northern Japan. Ecol Indic 50:79-89. https://doi.org/10.1016/j. ecolind.2014.11.003

Farley KA, Jobbágy EG, Jackson RB (2005) Effects of afforestation on water yield: a global synthesis with implications for policy. Glob Chang Biol 11(10):1565-1576. https://doi.org/10.1111/j.13652486.2005.01011.x

Fu Q, Li B, Hou Y, Bi X, Zhang X (2017) Effects of land use and climate change on ecosystem services in Central Asia's arid regions: a case study in Altay prefecture, China. Sci Total Environ 607-608:633-646. https://doi.org/10.1016/j.scitotenv.2017.06.241

Gao J, Li F, Gao H, Zhou C, Zhang X (2017) The impact of land-use change on water-related ecosystem services: a study of the Guishui River basin, Beijing, China. J Clean Prod 163(S1):S148-S155. https://doi. org/10.1016/j.jclepro.2016.01.049 
Goulson D, Lye GC, Darvill B (2008) Decline and conservation of bumble bees. Annu Rev Entomol 53:191208. https://doi.org/10.1146/annurev.ento.53.103106.093454

Hagen LJ, Skidmore EL (1971) Turbulent velocity fluctuations and vertical flow as affected by windbreak porosity. Trans ASAE 14(4):634-637. https://doi.org/10.13031/2013.38355

Haines-Young R, Potschin M (2013) Common International Classification of Ecosystem Services (CICES): Consultation on Version 4. August-December 2012, EEA Framework Contract No EEA/IEA/09/003. https://cices.eu/. Accessed: 8 March 2018

Harrison PA, Vandewalle M, Sykes MT, Berry PM, Bugter R, de Bello F, Feld CK, Grandin U, Harrington R, Haslett JR, Jongman RHG, Luck GW, Martins da Silva P, Moora M, Settele J, Sousa JP, Zobel M (2010) Identifying and prioritising services in European terrestrial and freshwater ecosystems. Biodivers Conserv 19(10):2791-2821. https://doi.org/10.1007/s10531-010-9789-x

Hijmans RJ, Cameron SE, Parra JL, Jones PG, Jarvis A (2005) Very high resolution interpolated climate surfaces for global land areas. Int J Climatol 25(15):1965-1978. https://doi.org/10.1002/joc.1276

IGER (2002) Scoping the potential of farm ponds to provide environmental benefits. Final project report. Defra project ES0109. Defra. London, UK

IPBES (2016) Summary for policymakers of the assessment report of the Intergovernmental Science-Policy Platform on Biodiversity and Ecosystem Services on pollinators, pollination and food production. In: Potts SG, Imperatriz-Fonseca VL, Ngo HT, Biesmeijer JC, Breeze TD, Dicks LV, Garibaldi LA, Hill R, Settele J, Vanbergen AJ, Aizen MA, Cunningham SA, Eardley C, Freitas BM, Gallai N, Kevan PG, KovácsHostyánszki A, Kwapong PK, Li J, Li X, Martins DJ, Nates-Parra G, Pettis JS, Rader R, Viana BF (eds.) Secretariat of the Intergovernmental Science-Policy Platform on Biodiversity and Ecosystem Services, Bonn, Germany

Jensen ES, Peoples MB, Hauggaard-Nielsen H (2010) Faba bean in cropping systems. Field Crops Res 115(3): 203-216. https://doi.org/10.1016/j.fcr.2009.10.008

Jentsch A, Beierkuhnlein C (2008) Research frontiers in climate change: effects of extreme meteorological events on ecosystems. Compt Rendus Geosci 340(9-10):621-628. https://doi.org/10.1016/j.crte.2008.07.002

JRC (2012a) Temperature and rainfall GIS data. European Commission Joint Research Centre (JRC) European Soil Portal. Based on Hijmans et al. (2005). http://eusoils.jrc.ec.europa.eu. Accessed: 8 January 2018

JRC (2012b) Soil texture GIS data. European Commission Joint Research Centre (JRC) European Soil Portal. The European Soil Database (distribution version v2.0) (2003). http://eusoils.jrc.ec.europa.eu/ESDB Archive/ESDB_data_1k_raster_intro/ESDB_1k_raster_data_intro.html. Accessed: 8 January 2018

Justus M, Köpke U (1995) Strategies to reduce nitrogen losses via leaching and to increase precrop effects when growing faba beans. Biol Agric Hortic 11(1-4):145-155. https://doi.org/10.1080/01448765.1995.9754701

Kay P, Edwards AC, Foulger M (2009) A review of the efficacy of contemporary agricultural stewardship measures for ameliorating water pollution problems of key concern to the UK water industry. Agric Syst 99(2-3):67-75. https://doi.org/10.1016/j.agsy.2008.10.006

Kröger R, Scott JT, Czarnecki JMP (2014) Denitrification potential of low-grade weirs and agricultural drainage ditch sediments in the lower Mississippi Alluvial Valley. Ecol Eng 73:168-175. https://doi.org/10.1016/j. ecoleng.2014.09.019

Krutz LJ, Senseman SA, Zablotowicz RM, Matocha MA (2005) Reducing herbicide runoff from agricultural fields with vegetative filter strips: a review. Weed Sci 53(3):353-367. https://doi.org/10.1614/WS-03-079R2

Lindner M, Maroschek M, Netherer S, Kremer A, Barbati A, Garcia-Gonzalo J, Seidl R, Delzon S, Corona P, Kolström M, Lexer MJ, Marchetti M (2010) Climate change impacts, adaptive capacity, and vulnerability of European forest ecosystems. For Ecol Manag 259(4):698-709. https://doi.org/10.1016/j.foreco.2009.09.023

Maes J, Liquete C, Teller A, Erhard M, Paracchini ML, Barredo J, Grizzetti B, Cardoso A, Somma F, Petersen JE, Meiner A, Royo Gelabert E, Zal N, Kristensen P, Bastrup-Birk A, Biala K, Piroddi C, Egoh B, Degeorges P, Fiorina C, Santos-Martín F, Naruševičius V, Verboven J, Pereira HM, Bengtsson J, Gocheva K, MartaPedroso C, Snäll T, Estreguil C, San-Miguel-Ayanz J, Pérez-Soba M, Grêt-Regamey A, Lillebø AI, Malak DA, Condé S, Moen J, Czúcz B, Drakou EG, Zulian G, Lavalle C (2016) An indicator framework for assessing ecosystem services in support of the EU biodiversity strategy to 2020. Ecosyst Serv 17:14-23. https://doi.org/10.1016/j.ecoser.2015.10.023

Malinga R, Gordon LJ, Jewitt G, Lindborg R (2015) Mapping ecosystem services across scales and continentsa review. Ecosyst Serv 13:57-63. https://doi.org/10.1016/j.ecoser.2015.01.006

Maron M, Mitchell MGE, Runting RK, Rhodes JR, Mace GM, Keith DA, Watson JEM (2017) Towards a threat assessment framework for ecosystem services. Trends Ecol Evol 32(4):240-248. https://doi.org/10.1016/j. tree.2016.12.011

MEA (2005) Ecosystems and Human Well-being: Synthesis. Millennium Ecosystem Assessment (MEA). Island Press, Washington, DC

Morandin LA, Kremen C (2013) Hedgerow restoration promotes pollinator populations and exports native bees to adjacent fields. Ecol Appl 23(4):829-839. https://doi.org/10.1890/12-1051.1 
Needelman BA, Ruppert DE, Vaughan RE (2007) The role of ditch soil formation and redox biogeochemistry in mitigating nutrient and pollutant losses from agriculture. J Soil Water Conserv 62(4):207-215

Newton I (2004) The recent declines of farmland bird populations in Britain: an appraisal of causal factors and conservation actions. Ibis 146:579-600. https://doi.org/10.1111/j.1474-919X.2004.00375.X

Novara A, Gristina L, Saladino SS, Santoro A, Cerdà A (2011) Soil erosion assessment on tillage and alternative soil managements in a Sicilian vineyard. Soil Tillage Res 117:140-147. https://doi.org/10.1016/j. still.2011.09.007

Ockenden MC, Deasy C, Quinton JN, Surridge B, Stoate C (2014) Keeping agricultural soil out of rivers: evidence of sediment and nutrient accumulation within field wetlands in the UK. J Environ Manag 135:54 62. https://doi.org/10.1016/j.jenvman.2014.01.015

Ouyang Z, Zheng H, Xiao Y, Polasky S, Liu J, Xu W, Wang Q, Zhang L, Xiao Y, Rao E, Jiang L, Lu F, Wang X, Yang G, Gong S, Wu B, Zeng Y, Yang W, Daily GC (2016) Improvements in ecosystem services from investments in natural capital. Science 352(6292):1455-1459. https://doi.org/10.1126 /science.aaf2295

Overbeck GE, Vélez-Martin E, Scarano FR, Lewinsohn TM, Fonseca CR, Meyer ST, Müller SC, Ceotto P, Dadalt L, Durigan G, Ganade G, Gossner MM, Guadagnin DL, Lorenzen K, Jacobi CM, Weisser WW, Pillar VD (2015) Conservation in Brazil needs to include non-forest ecosystems. Divers Distrib 21(12):14551460. https://doi.org/10.1111/ddi.12380

Panagos P, Borrelli P, Poesen J, Ballabio C, Lugato E, Meusburger K, Montanarella L, Alewell C (2015) The new assessment of soil loss by water erosion in Europe. Environ Sci Pol 54:438-447. https://doi.org/10.1016/j. envsci.2015.08.012

Panagos P, Borrelli P, Meusburger K, Alewell C, Ballabio C (2017) Seasonal variation and climate change impact in rainfall erosivity across Europe. $19^{\text {th }}$ EGU General Assembly, EGU2017, proceedings from the conference held 23-28 April, 2017 in Vienna, Austria. p. 8466

QGIS Development Team (2017) QGIS geographic information system. Open Source Geospatial Foundation Project. https://www.qgis.org. Accessed: 8 January 2018

QuESSA (2017) Quantification of Ecosystem Services for Sustainable Agriculture (QUESSA) Project. http://www.quessa.eu/. Accessed: 8 January 2018

Reichenberger S, Bach M, Skitschak A, Frede H-G (2007) Mitigation strategies to reduce pesticide inputs into ground- and surface water and their effectiveness: a review. Sci Total Environ 384(1-3):1-35. https://doi. org/10.1016/j.scitotenv.2007.04.046

Rider NE (1952) The effect of a hedge on the flow of air. Q J R Meteorol Soc 78(335):91-101. https://doi. org/10.1002/qj.49707833515

Rodríguez-Echeverry J, Echeverría C, Oyarzún C, Morales L (2018) Impact of land-use change on biodiversity and ecosystem services in the Chilean temperate forests. Landsc Ecol 33(3):439-435. https://doi.org/10.1007 /s10980-018-0612-5

Ruiz-Colmenero M, Bienes R, Marques MJ (2011) Soil and water conservation dilemmas associated with the use of green cover in steep vineyards. Soil Tillage Res 117:211-223. https://doi.org/10.1016/j.still.2011.10.004

Runting RK, Bryan BA, Dee LE, Maseyk FJF, Mandle L, Hamel P, Wilson KA, Yetka K, Possingham HP, Rhodes JR (2017) Incorporating climate change into ecosystem service assessments and decisions: a review. Glob Chang Biol 23(1):28-41. https://doi.org/10.1111/gcb.13457

Sahin V, Hall MJ (1996) The effects of afforestation and deforestation on water yields. J Hydrol (Amst) 178(14):293-309. https://doi.org/10.1016/0022-1694(95)02825-0

Schwartz RC, Fryrear DW, Harris BL, Bilbro JD, Juo ASR (1995) Mean flow and shear stress distributions as influenced by vegetative windbreak structure. Agric For Meteorol 75(1-3):1-22. https://doi.org/10.1016 /0168-1923(94)02206-Y

SEP (2015) Ecosystem Services and the Environment. In-depth Report 11. Science for Environment Policy (SEP). Produced for the European Commission, DG Environment by the Science Communication Unit, University of the West of England (UWE), Bristol, UK

SEP (2016) Identifying emerging risks for environmental policies. Future Brief 13. Science for Environment Policy (SEP). Produced for the European Commission DG Environment by the Science Communication Unit, University of the West of England (UWE), Bristol, UK. doi:https://doi.org/10.2779/080121

Shackelford G, Steward PR, Benton TG, Kunin WE, Potts SG, Biesmeijer JC, Sait SM (2013) Comparison of pollinators and natural enemies: a meta-analysis of landscape and local effects on abundance and richness in crops. Biol Rev Camb Philos Soc 88(4):1002-1021. https://doi.org/10.1111/brv.12040

Shepherd MA (1999) The effectiveness of cover crops during eight years of a UK sandland rotation. Soil Use Manag 15(1):41-48. https://doi.org/10.1111/j.1475-2743.1999.tb00062.x

Shore M, Jordan P, Mellander P-E, Kelly-Quinn M, Melland AR (2015) An agricultural drainage channel classification system for phosphorus management. Agric Ecosyst Environ 199:207-215. https://doi. org/10.1016/j.agee.2014.09.003 
Smith DR (2009) Assessment of in-stream phosphorus dynamics in agricultural drainage ditches. Sci Total Environ 407(12):3883-3889. https://doi.org/10.1016/j.scitotenv.2009.02.038

Temple HJ, Terry A (Compilers) (2007) The status and distribution of European mammals. Luxembourg: Office for Official Publications of the European Communities

Tolessa T, Senbeta F, Kidane M (2017) The impact of land use/land cover change on ecosystem services in the central highlands of Ethiopia. Ecosyst Serv 23:47-54. https://doi.org/10.1016/j.ecoser.2016.11.010

Tzilivakis J, Warner D, Green A, Lewis KA (2015a) Adapting to climate change: assessing the vulnerability of ecosystem services in Europe in the context of rural development. Mitig Adapt Strat GL 20(4):547-572. https://doi.org/10.1007/s11027-013-9507-6

Tzilivakis J, Warner D, Green A, Lewis KA (2015b) Guidance and tool to support farmers in taking aware decisions on ecological focus areas: final report for project JRC/IPR/2014/H.4/0022/NC. Joint Research Centre (JRC), European Commission

Tzilivakis J, Warner DJ, Green A, Lewis KA, Angileri V (2016) An indicator framework to help maximise potential benefits for ecosystem services and biodiversity from ecological focus areas. Ecol Indic 69:859872. https://doi.org/10.1016/j.ecolind.2016.04.045

Ucar T, Hall FR (2001) Windbreaks as a pesticide drift mitigation strategy: a review. Pest Manag Sci 57(8):663675. https://doi.org/10.1002/ps.341

Vanbergen AJ (2013) Threats to an ecosystem service: pressures on pollinators. Front Ecol Environ 11(5):251259. https://doi.org/10.1890/120126

Vörösmarty CJ, McIntyre PB, Gessner MO, Dufgeon D, Prusevich A, Green P, Glidden S, Bunn SE, Sullivan CA, Reidy Liermann C, Davies PM (2010) Global threats to human water security and river biodiversity. Nature 467:555-561. https://doi.org/10.1038/nature09440 Data available at: viewable at: https://databasin. org/maps/new\#datasets=b1bff1d404ca45c1aebdb3289fe6140f. Accessed: 8 January 2018

Wilby RL, Orr H, Watts G, Battarbee RW, Berry PM, Chadd R, Dugdale SJ, Dunbar MJ, Elliott JA, Extence C, Hannah DM, Holmes N, Johnson AC, Knights B, Milner NJ, Ormerod SJ, Solomon D, Timlett R, Whitehead PJ, Wood PJ (2010) Evidence needed to manage freshwater ecosystems in a changing climate: turning adaptation principles into practice. Sci Total Environ 408(19):4150-4164. https://doi.org/10.1016/j. scitotenv.2010.05.014

Wratten SD, Gillespie M, Decourtye A, Mader E, Desneux N (2012) Pollinator habitat enhancement: benefits to other ecosystem services. Agric Ecosyst Environ 159:112-122. https://doi.org/10.1016/j.agee.2012.06.020 